\title{
1 Can Mn-S redox cycling drive sedimentary dolomite formation? A hypothesis
}

2

17

18

${ }^{a}$ Department of Earth and Atmospheric, University of Alberta, Edmonton, Alberta, Canada T6G Daniel A. Petrash ${ }^{\mathrm{a} *}$; Stefan V. Lalonde ${ }^{\mathrm{b}}$; Gabriela González ${ }^{a}$; Robert A. Gordon ${ }^{\mathrm{c}}$; José A. Méndez ${ }^{\mathrm{d}}$; Murray K. Gingras ${ }^{\mathrm{a}}$; Kurt O. Konhauser ${ }^{\mathrm{a}}$ 5

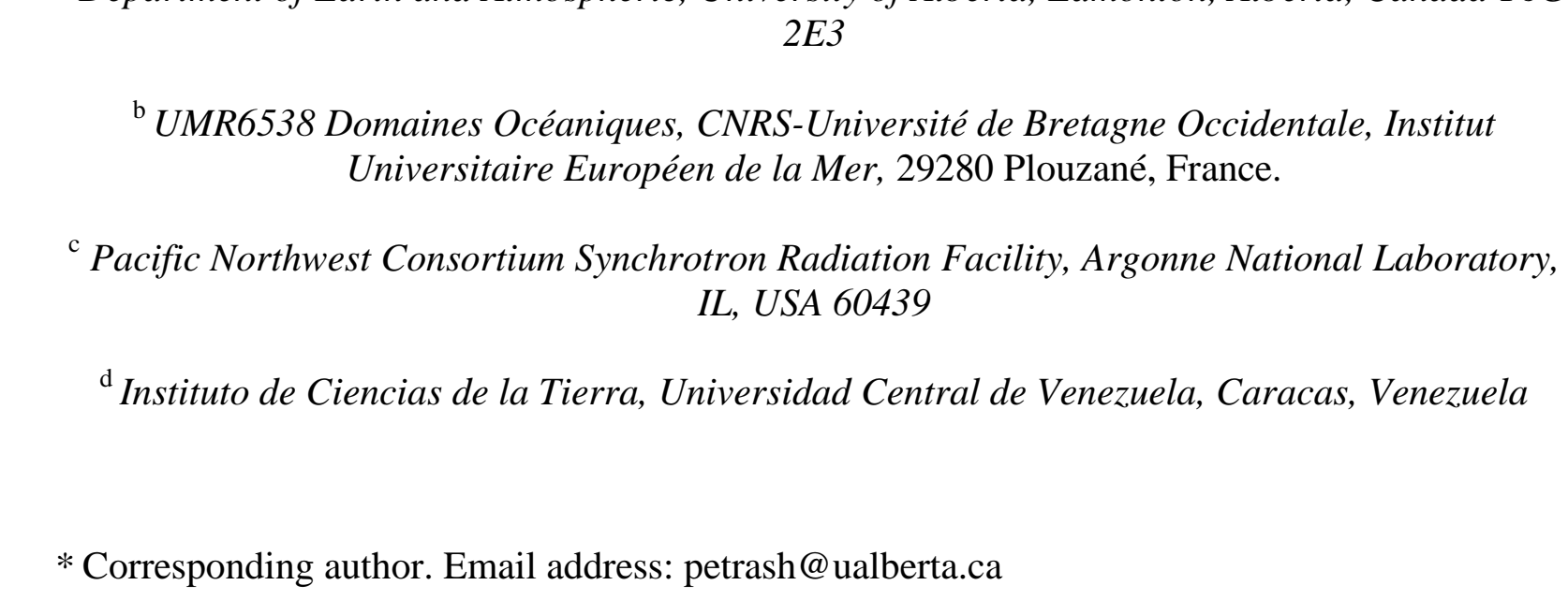

KEYWORDS: Mn-cycling; peritidal dolomite; synsedimentary dolomite; microbial mats; shallow burial diagenesis 


\section{ABSTRACT}

2 The formation of dolomite in modern peritidal environments is linked to the degradation of

3 buried microbial mats, with complexation of $\mathrm{Ca}$ and $\mathrm{Mg}$ by extracellular polysaccharides (EPS)

4 and alkalinity generation through organic carbon respiration facilitating the nucleation of

5 dolomite precursors. In the past two decades, microbial sulfate reduction, methanogenesis, and

6 methanotrophy have all been considered as potential drivers of the nucleation process, but it

7 remains unclear why dolomite formation could not also occur in suboxic sediments where

8 abundant alkalinity is produced by processes linked to $\mathrm{Mn}(\mathrm{IV})$ and/or Fe(III) reduction coupled

9 with the diffusion and reoxidation of reduced sulfur species. Here we report the interstitial

10 occurrence of spheroidal aggregates of nanometer-scale Ca-rich dolomite rhombohedra within

11 suboxic sediments associated with remnant microbial mats that developed in the peritidal zone of

12 the Archipelago Los Roques, Venezuela. Multiple analytical tools, including EPMA, ICP-MS,

13 synchrotron-based XRF and XRD, and spatially resolved XANES microanalyses, show that the

14 dolomite-cemented interval exhibits depleted bulk iron concentrations, but is interstitially

15 enriched in $\mathrm{Mn}$ and elemental sulfur $\left(\mathrm{S}^{0}\right)$. Manganese occurs in several oxidation states,

16 indicating that the dolomite-cemented interval was the locus of complex biological redox

17 transformations characterized by coupled $\mathrm{Mn}$ and S cycling. The tight correspondence between

18 sedimentary $\mathrm{Mn}$ and $\mathrm{MgCO}_{3}$ concentrations further hint at a direct role for $\mathrm{Mn}$ during

19 dolomitization. While additional studies are required to confirm its relevance in natural settings,

20 we propose a model by which coupled $\mathrm{Mn}-\mathrm{S}$ redox cycling may promote alkalinity generation

21 and thus dolomite formation in manner similar to, or even more efficiently, than bacterial sulfate

22 reduction alone. 
2 In the peritidal zone of most Holocene carbonate platforms, Ca-dolomite formation has been

3 linked to the near-surface decay of microbial mats (e.g., Kendall and Skipwith, 1968; Gebelein

4 and Hoffman, 1973; Davies et al., 1975; von der Borch and Lock, 1979) that were rapidly buried

5 during sediment progradation (Hardie and Shinn, 1986). While modern hypersaline microbial

6 mats are functionally diverse (Des Marais, 2003), their upper trophic structure is generally

7 composed of halophilic cyanobacteria living in close association with halotolerant algae and

8 other oxygenic and anoxygenic autotrophs, while the deeper levels contain various heterotrophic

9 communities which couple the oxidation of buried organic carbon to the reduction of available

10 terminal electron acceptors (TEAs). These TEAs include (in decreasing order of energy yield),

11 oxygen, nitrate, manganese, iron, sulfate, and ultimately dissolved inorganic carbon (Froelich et

12 al., 1979). The progressive depletion of TEAs often leads to sharp biogeochemical interfaces that

13 may favor the precipitation of authigenic minerals, such as calcite, phosphates, pyrite and/or

14 dolomite (see Konhauser, 2007).

15 The fact that dolomite is abundant in the geologic record yet is rarely observed forming

16 today (the so-called "dolomite problem") is complicated by the fact that $\mathrm{Mg}$ in seawater today is

17 largely found in complexed form (cf. Arvidson and Mackenzie, 1999). In the limited number of

18 modern dolomite-forming systems known today, this is thought to be overcome in several ways.

19 The extracellular polymeric substances (EPS) produced by benthic microbes facilitate the

20 sorption and accumulation of $\mathrm{Ca}, \mathrm{Mg}$, and various trace metals, and may also act as a mineral

21 nucleation template (Défarge et al., 1996; Braissant et al., 2007; 2009; Wang et al. 2009). Recent

22 work by Roberts et al. (2013) details how the variety of carboxylated macromolecules

23 comprising EPS may catalyze the precipitation of dolomite through complexation and 
1 dehydration of $\mathrm{Mg}^{2+}$ ions (see also Kenward et al., 2013). The anaerobic respiration of organic

2 carbon shifts the $\mathrm{pH}$ towards alkaline values and increases the activity of $\mathrm{CO}_{3}{ }^{2-}$ ions, both

3 favoring dolomite saturation by displacing water dipoles bonded to the surface of magnesium

4 cations (Lippmann 1973; Slaughter and Hill 1991; Défarge et al., 1996 Castanier et al., 1999;

5 Raz et al., 2000; Decho et al., 2005; Gilbert et al., 2005; Visscher and Stolz, 2005; Kwak et al,.

6 2005; Braissant et al., 2007; Wang et al., 2009; Gallagher et al., 2012). It is by this combination

7 of biologically-influenced (i.e., ion adsorption and mineral templating) and biologically-induced

8 (metabolically-controlled) mechanisms (cf. Dupraz et al., 2009) that points to many

9 heterotrophic bacteria being capable of facilitating Ca-dolomite nucleation. Yet, the anaerobic

10 respiratory pathway that has received the most attention in terms of diagenetic carbonate mineral

11 formation is bacterial sulfate reduction (Vasconcelos et al., 1995; Vasconcelos and McKenzie,

12 1997; Wright, 1999; Wright and Wacey, 2005; Warthmann et al., 2000; Van Lith et al., 2003;

13 Sánchez-Román et al., 2009). While studying dolomite formation in hypersaline mats from

14 Lagoa Vermelha, RJ, Brazil, Moreira et al. (2004) concluded that the mineral actually forms as a

15 result of undersaturation of competing carbonate phases due to sulfide oxidation. Similarly, it has

16 been proposed that sulfide ions or some organic ligands may promote $\mathrm{Mg} 2+$ dehydration at the

17 surface of a solid precursor phase resulting in dolomite nucleation/precipitation reactions (Zhang

18 et al., 2012; Yang et al., 2012, see also Roberts et al., 2013).

19 It is thus apparent that a variety of mechanisms, non-exclusive in nature, can act as

20 potential promoters of dolomite formation. In some marine sediments, the activity of subsurface

$21 \mathrm{Mn}(\mathrm{IV})-$ and $\mathrm{Fe}(\mathrm{III})$-reducing bacteria exert a quantitatively important control over rates of

22 organic carbon mineralization (Aller and Rude, 1988; Aller, 1990, 1994; Canfield et al., 1993a,b;

23 Thamdrup et al., 1994), and not surprisingly, these microorganism have also been found 
1 potentially associated with dolomite precipitation (see for instance Compton, 1992; Curtis et al.,

2 2000; Breuker et al., 2013). However, sedimentary evidence for links between metal respiration

3 during suboxic diagenesis and dolomite formation has yet to be reported.

4 In this study we employ a high resolution chemostratigraphic approach, complemented

5 by synchrotron-based microscale analyses and microbial surface chemical characterization

6 (potentiometric and FTIR), with the goal of examining the formation of dolomite in association

7 with buried microbial mats of hypersaline lagoonal sediments in the Archipelago Los Roques,

8 Venezuela, and specifically the potential role of electron acceptors other than sulfate in the

9 dolomitization process. We describe a surprising relation between the subsurface availability of

10 manganese and the abundance of dolomite at this site, where it appears that progressive

11 degradation of a rapidly buried microbial mat system produced a geochemical disequilibrium

12 zone marked by the availability, and recycling, of intermediate manganese and sulfur species.

13 We propose a reaction model whereby intermediate $\mathrm{Mn}(\mathrm{III})$ phases, formed via $\mathrm{Mn}(\mathrm{IV})$

14 reduction or $\mathrm{Mn}(\mathrm{II})$ oxidation, reacted with native and evolved $\mathrm{S}^{0}$, enhanced the degradation of

15 sedimentary organic matter, sustained favorable alkalinity and $\mathrm{pH}$, and ultimately, contributed to

16 the stabilization (i.e., progressive growth) of early formed dolomite precursors as

17 microcrystalline Ca-dolomite cements.

\section{2. Study site}

20 Francisqui is one of the many cays comprising the Archipelago Los Roques, an arid isolated 21 carbonate platform located $150 \mathrm{~km}$ from the Venezuelan coastline in the Caribbean Sea (see Fig.

22 1A). The platform developed over an uplifted lithospheric block whose age, petrography, 23 geochemistry, and tectono-magmatic history are similar to exposures of the Caribbean Plate on 
1 the nearby Leeward Antilles islands (see Wright and Wyld, 2010). The restricted lagoon sampled

2 (Fig. 1B) has an areal extent of about $7,100 \mathrm{~m}^{2}$; it is shallow (average water depth $<15 \mathrm{~cm}$ ),

3 alkaline $\left(\mathrm{pH}=9.3 ; \mathrm{CaCO}_{3}\right.$ total $\left.=259 \mathrm{meq} / \mathrm{L}\right)-$ as determined in the field, and hypersaline

$4 \quad$ (salinity $=138-141 \%$ ) - as determined in the lab (using measured $\mathrm{Cl}^{-}$concentrations). Other

5 relevant chemical features of the lagoon water are summarized in Tables 1 and 2, and its

6 predicted saturation states with regards to a variety of minerals are shown Table 2 . The lagoon

7 has been infilled by accretion of sediments of both authigenic and allogenic (storm transported)

8 origin (i.e., Hardie and Shinn, 1986). A subaqueous microbial mat, composed of both

9 photosynthetic and non-photosynthetic microbes, has developed across the lagoon due to the

10 suppression of most grazing activity under the hypersaline conditions governing this

11 environment (Fig. 1C-D). The organic-rich mud-dominated lagoonal succession reflects annual

12 low amplitude fluctuations of the lagoon water level (Fig. 1C). The range of such oscillations is

13 controlled by seepage reflux, and sporadically by storm events. The sedimentary distribution of

14 organic matter is greatly influenced by such autocyclic controls, and fossil analogues to the

15 surficial mat have been buried due to active sediment accumulation.

\section{3. Methods}

18 With the goal of investigating the formation of dolomite in association with the oxidation of the

19 buried microbial mats and the potential role of electron acceptors other than sulfate, we

20 combined information obtained via bulk sediment digestion and Inductively Coupled Plasma -

21 Quadrupole Mass Spectrometry (ICP-QMS) with a range of textural, mineralogical and in situ

22 geochemical analyses. We also evaluated the reactivity of the surficial microbial mats by 
1 potentiometric titration and applied a surface complexation model that benefits from

2 complimentary Fourier Transform Infrared Spectroscopy (FTIR) data.

$4 \quad 3.1$ Sample collection

5 A Glew Gravity Corer (Glew, 1991) was used to collect $30 \mathrm{~cm}$-long vertical cores of lagoon

6 sediments. The cores were then extruded and sliced into $0.5 \mathrm{~cm}$ subsamples, for the first $6 \mathrm{~cm}$,

7 and then into $2 \mathrm{~cm}$ subsamples for the deeper part of the core. Sub-samples of the organic rich

8 sediments were placed in sterile $0.5 \mathrm{ml}$ Eppendorf PCR polypropylene tubes containing filtered

9 lagoon water and aqueous glutaraldehyde to a final concentration of $2 \% \mathrm{v} / \mathrm{v}$. The overlying

10 surface waters were sampled in duplicate and filtered through Spectra micropore 0.22- $\mu \mathrm{m}$ filters.

11 One of the aliquots was immediately acidified with concentrated trace metal-free $\mathrm{HNO}_{3}$ for

12 cation analyses, and the other left unacidified for anion analysis. The sediment subsamples were

13 freeze-dried prior to further analyses. The samples were kept refrigerated $\left(3^{\circ} \mathrm{C}\right)$ prior to all

14 sample preparation and analyses.

163.2 Bulk mineralogical analysis

17 The mineralogy of freeze-dried bulk sediments $(0-30 \mathrm{~cm}$ depth) were determined at a vertical

18 resolution of $2 \mathrm{~cm}$ by X-ray Diffraction (XRD), with patterns produced using a Rigaku

19 Geigerflex Power Diffractometer with Co-K $\alpha$ radiation generated at $50 \mathrm{kV}$ and $25 \mathrm{~mA}$, a step

20 size of $0.5^{\circ} 2 \theta \cdot \mathrm{step}^{-1}$, and an accumulation time of $2 \mathrm{~s} \cdot \mathrm{step}^{-1}$. In the samples where dolomite was

21 found, we optimized the XRD in the interval 29 to $38^{\circ} 2 \theta$ using the $d_{101}$ peak of quartz for

22 calibration purposes. The refined XRD patterns were obtained at $0.2^{\circ} 2 \theta \cdot \mathrm{min}^{-1}$, and a step size of $230.004^{\circ} 2 \theta \cdot \operatorname{step}^{-1}$ (after Jones et al. 2001). 


\section{$2 \quad 3.3$ Electron microscopy}

3 Scanning Electron Microscopy (SEM) observations of both the surface microbial mat and the

4 dolomite-bearing sediments were performed on a JEOL JSM-6301FXV instrument connected to

5 a Norvar Energy-Dispersive Spectrometer (EDS). Freshly broken samples were graphite coated

6 for SEM observation, while others were cryo-sectioned and observed by Transmission Electron

7 Microscopy (TEM). The SEM analyses were done at accelerating voltages of $5 \mathrm{kV}$ (20 kV for

8 EDS), and at a working distance of $11 \mathrm{~mm}$. The accelerating voltage of TEM was $80 \mathrm{kV}$ (see

9 Petrash et al., 2012 for further details).

\subsection{Solid phase geochemistry}

12 Samples were freeze dried and powdered before analysis. For minor and trace element 13 composition, a mass of $\sim 200 \mathrm{mg}$ of each sediment subsample was digested using analytical grade

$14 \mathrm{HNO}_{3}(8 \mathrm{~N})$ to ensure dissolution of all but the most refractory detrital grains. The transition

15 metal concentrations were determined by ICP-QMS using a PerkinElmer Elan6000 instrument.

16 The Total Organic Carbon (TOC) and Total Nitrogen (TN) of sediment subsamples were

17 determined using the Dumas Combustion Method in a Costech 4010 Elemental Analyzer. We

18 complemented our bulk ICP-QMS analyses with laser ablation (LA) ICP-QMS (28 laser spots)

19 in order to measure $\mathrm{Mg}, \mathrm{Mn}, \mathrm{Fe}$, and $\mathrm{Sr}$ concentrations of the sediments comprising the interval

20 from 8 to $14 \mathrm{~cm}$ depth, where Ca-dolomite was identified via XRD. Ca-concentrations, obtained

21 via WDX (see below), were used as internal standards and the USGS analytical standard MACS-

223 was used to derive the trace metal concentrations of the samples. Measuring conditions and

23 detection limits are as described in Petrash et al. (2012). 
2 3.4.1 Sorptive properties of the microbial mats and their influence on sediments

3 In order to evaluate the sorptive properties of individual layers comprising the microbial mat,

$4500 \mathrm{mg}$ (dry weight) sub-samples of the green (upper) and purple (lower) layers of the mat at the

5 sediment water-interface were examined by potentiometric acid-base titration. Samples were first

6 washed with four alternating wash and harvest cycles (10-s agitation followed by 10-min soak

7 and centrifugation at 11,050 g) at circumneutral $\mathrm{pH}$ with ultra-pure (18.2 MOhm) water in order

8 to replace interstitial waters and release surface-complexed elements (e.g., Lalonde et al., 2007).

9 Samples were then suspended in $\sim 40 \mathrm{ml}$ of $0.01 \mathrm{M} \mathrm{NaNO}_{3}$ titration electrolyte and adjusted to

$10 \mathrm{pH} \sim 3$ with concentrated analytical grade $\mathrm{HNO}_{3}$. Sub-samples were titrated up from $\mathrm{pH} \sim 3$ to $\mathrm{pH}$

1111 and a surface complexation model was fitted to the resulting excess charge data following the

12 methods of Lalonde et al. (2007, 2010). Briefly, the set of functional groups (in terms of

13 concentrations and proton stability constants) that best account for the excess charge data for

14 each titration were determined by linear programming over a fixed grid of possible $\mathrm{pK}_{a}$ values

15 (in this case, 4-10 in 0.2 increments). We also conducted synchrotron-based FTIR using a Ge IR

16 attachment for attenuated total internal reflection. These analyses were conducted at the Mid IR

17 Beamline (01B1-1) at the Canadian Light Source, and provide identification of the organic

18 ligands contributing to the surface reactivity of the surficial microbial mat with high spatial

19 resolution and minimum sample preparation.

20 To evaluate the extent to which biologically important metals are transferred from

21 ambient waters to the surficial microbial mats and subsurface sediments, we examined Ca-

22 normalized distribution coefficients between lagoon water $\left([\mathrm{Me}]_{1 \mathrm{w}} /[\mathrm{Ca}]_{\mathrm{lw}}\right)$ and bulk sediments

$23\left([\mathrm{Me}]_{\mathrm{Sed}} /[\mathrm{Ca}]_{\mathrm{Sed}}\right)$. In the context of the uppermost mat layer, this approach provides an indication 
1 of the affinity of the mat for certain biologically important metals, and variation down core

2 reveal shifts in the mobility of these elements upon burial and diagenesis. Elemental distribution

3 coefficients for the mat and underlying sediments were calculated using the relation:

$4 \quad \mathrm{D}_{\mathrm{Me}}=\left([\mathrm{Me}]_{\mathrm{Sed}} /[\mathrm{Me}]_{\mathrm{lw}}\right) \cdot\left([\mathrm{Ca}]_{\mathrm{lw}} /[\mathrm{Ca}]_{\mathrm{Sed}}\right)$

\section{3.4.2. Statistical characterization of the sedimentary chemofacies}

7 A Spearman rank correlation coefficient $\left(r_{s}, p<0.001\right)$ was used as a non-parametric measure of 8 the strength and direction of association between any two parameters of interest. Geochemical

9 behavior and correlation amongst elements throughout the sedimentary pile (fraction soluble in

$108 \mathrm{M} \mathrm{HNO}_{3}$, thus excluding refractory detrital minerals) were further examined by hierarchal

11 cluster analysis, which offers a secondary and objective test of the elemental grouping in each

12 diagenetic zone. The data standardization and clustering protocols implemented here (Filzmoser

13 and Hron, 2008; Montero-Serrano et al., 2010) emphasize the relative similarity between

14 analytes by means of squared normalized Euclidian distances. The analyses were performed

15 using the Multi-Variate Statistical Package R.

\subsection{Aqueous geochemistry}

18 Overlying water temperatures and $\mathrm{pH}$ values were measured immediately upon collection using a 19 Ross (Orion) combination $\mathrm{pH}$ electrode and salinity-matched buffers, and $\mathrm{pH}$ values are reported

20 on the operational scale (Covington and Whitefield, 1988). Alkalinity was measured in situ by 21 acid titration and a mixed $\mathrm{pH}$ indicator. Results are expressed as calcium carbonate $\left(\mathrm{CaCO}_{3}\right)$. 22 Quantitative analyses of $\mathrm{SO}_{4}{ }^{2-}$ and $\mathrm{Cl}^{-}$anions in the surficial lagoon water samples were 23 performed using a Dionex DX600 Ion Chromatograph. We derive salinity (S) from chlorine 
1 concentrations by using the empirical relationship S $(\%)=1.80655\left[\mathrm{Cl}^{-}\right]$. Filtered and non-

2 acidified samples were diluted as required before analysis to reduce salinity to operational values

3 adequate for the analytical machine. Field measurements of temperature, $\mathrm{pH}$, dissolved oxygen

4 and alkalinity, and the chemical analyses of the water samples were used as input data to

5 calculate the distribution of aqueous species, ion activities, and mineral saturation indices that

6 indicate the tendency of a water to dissolve or precipitate relevant mineral phases (see Drever,

7 1988). The model was computed using the chemical speciation code WATEQ4F (Ball and

8 Nordstrom, 1991) as implemented in PHREEQC (Parkhust and Appelo, 1999), and assumes

9 homogeneous aqueous phase equilibria, except for redox species. The thermodynamic database

10 used is Nordstrom et al. (1990), revised by Ball and Norstrom (1991) for gypsum. Equilibrium

11 with respect to mineral solubilities is not assumed. The program results are used primarily to

12 place constraints on interpreting the precipitation conditions at the sediment-water interface. For

13 determination of major and trace metal compositions of the lagoon water, the samples were

14 digested with $\mathrm{HNO}_{3}(8 \mathrm{~N})$ and analyzed according to standard procedures (e.g., Windom et al.,

15 1989) using the quadrupole ICP-MS instrument described above.

\section{$17 \quad 3.6$ Electron Probe microanalyses (EPMA)}

18 The in situ distributions and concentrations of major elements $\mathrm{Ca}, \mathrm{Mg}, \mathrm{Mn}, \mathrm{S}$, and $\mathrm{P}$ in sediments

19 comprising the dolomite-bearing zone were determined using Wavelength Dispersive X-ray

20 Spectroscopy (WDS) with a JEOL JXA-8900 electron microprobe operated at an accelerating

21 voltage of $15 \mathrm{kV}$, focused beam diameter of $40 \mu \mathrm{m}\left(A \approx 1,256.6 \mu \mathrm{m}^{2}\right)$, and an average current of

$2210 \mathrm{nA}$. Count times were $20 \mathrm{~s}$ on each peak and half that for background measurements;

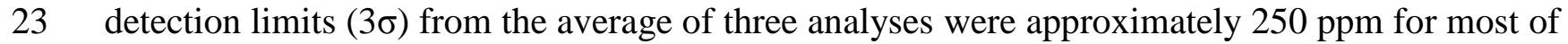


1 the analyzed oxides. A combination of natural and synthetic mineral, oxide, and metal standards

2 were used to reduce counts to weight percent concentrations using the CITZAF method with $\varphi \rho Z$

3 calculation.

4

$5 \quad 3.7$ Synchrotron-based microanalyses

6 All synchrotron-based elemental microanalyses were conducted under high-resolution conditions

7 by tuning the excitation energy to desired levels using a $\mathrm{Si}$ (111) double-crystal monochromator

8 installed at beamline 20 ID at the Advanced Photon Source (APS) in Argonne, IL.

10 3.7.1. Micro X-ray fluorescence $(\mu-X R F)$

11 The in situ distributions and concentrations of $\mathrm{Mn}, \mathrm{Fe}, \mathrm{Co}, \mathrm{Ni}, \mathrm{Zn}$, and $\mathrm{Sr}$ in the dolomite-

12 bearing sediment layer were determined via hard X-ray microprobe analyses. The excitation

13 energy was tuned at $20.196 \mathrm{keV}$ and a flux of $10^{10}$ to $10^{11}$ photons-per-second micro-focused

14 over an analytical area of $\sim 30 \mathrm{~m}^{2}$ using Kirkpatrick-Baez (KB) mirrors. The resulting

15 fluorescence spectra were measured using a 4 element Vortex multi-element Si drift detector

16 located at $90^{\circ}$ to the incident beam in the direction of the polarization, and operated with a $25 \mu \mathrm{m}$

17 Kapton window aligned at $142^{\circ}$ to the incident beam for a final energy resolution of $\sim 30 \mathrm{eV}$ per

18 channel. Semi-quantitative $\mu$-XRF results were obtained via calibration of relative element

19 sensitivities against a chemically homogeneous zone of the USGS MACS-3 reference material.

20 Spectral acquisition involved counting for $60 \mathrm{~s}$. Net intensities of the fluorescence peaks were

21 determined by fitting the complete emission line series of each spectrum in the computer code

22 PyMca v.4.6.2 (Solé et al., 2007). 


\subsection{2. $\mu$-XANES and $\mu-X R D$}

2 We used $\mu$-XANES for determining the oxidation state and coordination chemistry of Mn in the

3 micritic cements. The pre-edge features were collected in the energy range 6.450-6.690 keV; the

4 main edge crest was collected with $0.50 \mathrm{eV}$ steps, then with 0.05 steps until $200 \mathrm{eV}$ above the

5 absorption edge. XANES results were aligned using the K-edge of a Mn foil standard measured

6 in parallel with the sample (i.e., Kraft et al., 1996) with no energy shifts between scans observed

7 for the simultaneously-measured Mn foil reference. Nine individual Mn K-edge XANES scans

8 were averaged in energy before background removal and normalization to unit edge-step using

9 ATHENA (Ravel and Newville, 2005). Semi-quantitative analysis of these bulk merged Mn K-

10 edge XANES spectra was done through a linear combination-least squares fitting using four

11 model compounds: $\mathrm{Mn}_{2} \mathrm{O}_{3}, \mathrm{MnCO}_{3}, \square-\mathrm{MnOOH}$, and $\mathrm{Mn}_{3} \mathrm{O}_{4}$. At the end of spectral data

12 collection, the mineralogy of the microanalytical area subjected to XANES was evaluated by

13 integrating its bulk 2D-XRD reflection patterns, produced via a KB micro-focused beam

$14(\lambda=0.6139 \AA)$, using the computer code FIT2D (Hammersley, 1998). Correction of the

15 experimental geometry and $2 \theta$ calibration was made possible by also measuring the reflection

16 patterns of $\mathrm{LaB}_{6}$.

\section{4. Results and Discussion}

19 4.1. Sorptive properties of the living microbial mat

20 Concentrations and acidity constant $\left(\mathrm{pK}_{a}\right)$ values of proton-binding sites modelled from acid-

21 base titration data reveal very little difference between the upper (green) and lower (purple)

22 layers comprising the living microbial mat (Fig. 2A). The total site density in the surficial

23 microbial mat was found to be $3.10 \pm 0.63 \mathrm{~mol} \cdot \mathrm{kg}^{-1}$ (dry). The $\mathrm{pK}_{a}$ distribution of chemical 
1 functional groups (Fig. 2A) shows three buffering zones that we attribute to carboxyl groups

2 (apparent $\mathrm{pK}_{a}$ at $4.03 \pm 0.32$ ), the combined buffering capacity of phosphoryl and thiol groups

3 (apparent $\mathrm{pK}_{a}$ at $6.2 \pm 0.85$ ), and amino groups (apparent $\mathrm{pK}_{a}$ at $9.32 \pm 0.60$ ) (see Fein et al.,

4 1997; Braissant et al., 2007). A contribution from thiol functional groups is not only supported

5 by the significant accumulation of intra- and extracellular-sulfur in these mats (see Fig. 2B), but

6 also by the FTIR spectral data (Fig. 2C) that shows peaks at $2550-2620 \mathrm{~cm}^{-1}$ which are

7 characteristic of S-H stretching. While more acidic carboxyl, phosphoryl, and thiol groups are

8 more commonly implicated as the primary sites responsible for metal sorption (e.g., Boyanov et

9 al., 2003; Lalonde et al., 2010), the concentration of the third site (amino groups) was found to

10 exceed the combined concentration of the first and second buffering zones (Fig. 2A). This has

11 been previously reported for bacterial cultures producing copious amounts of EPS (Lalonde et

12 al., 2005; Braissant et al., 2007), and is consistent with visual and TEM observations (Fig. 2D)

13 affirming the EPS-rich nature of the living microbial mat in this study.

14 At the $\mathrm{pH}$ of the lagoon water $(\mathrm{pH} 9.3)$ most of the reactive sites identified here will be in

15 deprotonated state (see Fig. 2A) and available to bind dissolved metal cations (Geesey and Jang,

16 1989: Decho, 2000). The natural abundance and activity of these cations in the alkaline lagoon

17 water, together with competition based on their ionic radii, charge, and specific organic and

18 inorganic ligand-metal binding constants (Fraústo da Silva and Williams, 2001), determines

19 which metals are preferentially sequestered by the microbial mat surface (see Table 1, Fig. 2D).

20 Based solely on the total concentration of reactive sites determined for the surficial mat biomass,

21 we calculate that the burial of an equivalent $\sim 2$ cm-thick microbial mat (estimated $\rho=1.15$

$22 \mathrm{~kg} / \mathrm{m}^{3}$ ) could sequester and transport between 59 to $86 \mathrm{mmol} \mathrm{m}^{-2}$ of alkali and transition metals 23 to the subsurface. 
4.2. High resolution chemostratigraphy

3 Solid phase geochemical data reflects exchange and equilibrium between reactive solid phases

4 and pore fluids. The elemental distribution coefficients in the sediments, $\mathrm{D}_{\mathrm{Me}}$, reveal three

5 distinct biogeochemical zones, or chemofacies (Fig. 3). These reflect the variable redox

6 behaviour down core of transition metals (e.g., $\mathrm{Mn}, \mathrm{Ni}, \mathrm{Co}$, and $\mathrm{Fe}$ ) which form highly insoluble

7 oxides in oxic pore waters, and elements (e.g., Mo and Re) which occur as highly soluble anionic

8 species in oxic and suboxic waters and are rendered insoluble under more reducing conditions

9 where they co-precipitate with sulfides (Tribovillard et al., 2006). These general patterns of

10 metal distribution are also evident in a dendogram (Fig. 4).

\section{4.2.1 Chemofacies I}

13 From the water-sediment interface downwards to about $6 \mathrm{~cm}$ depth is an interval characterized

14 by a general decrease in the concentrations of various transition metals, including Fe, Mo and

$15 \mathrm{Cu}$. Both $\mathrm{Fe}(\mathrm{III})$ and $\mathrm{Mn}(\mathrm{IV})$ reduction occur in this zone consisting of the surficial living mat

16 and sediments immediately below, with solid-phase Fe concentrations being about one order of

17 magnitude higher than $\mathrm{Mn}$. The $\log \mathrm{D}$ trend of $\mathrm{Cu}$ closely parallels that of $\mathrm{Mo}\left(\mathrm{r}_{\mathrm{S}}=0.92, \mathrm{p}<\right.$

18 0.001) (Fig. 3). The trend in Mo and $\mathrm{Cu}$ depletion also correlates with that of TOC $\left(\mathrm{r}_{\mathrm{S}}=0.54, \mathrm{p}<\right.$

$190.001)$ and $\mathrm{C} / \mathrm{N}$ values $\left(\mathrm{r}_{\mathrm{S}}=0.68, \mathrm{p}<0.001\right)$, pointing to the role of organic matter as a sink for

20 these metals. The base of this chemofacies is a local minimum in all solid phase redox sensitive 21 metals (Fig. 3). 
1 Below Chemofacies I is a transitional zone, from $\sim 6$ to $12 \mathrm{~cm}$ depth, which spans the dolomite-

2 bearing buried microbial mat horizon, and in which bulk sediment Mn exhibits a concentration

3 maximum concomitant with decreased bulk sediment $\mathrm{Fe}$ concentration and relatively low

4 concentrations of $\mathrm{Mo}$ and $\mathrm{Cu}$ (Fig. 3). Chemofacies II exhibits peak bulk sediment $\mathrm{Mg}$

5 concentrations (as $\mathrm{MgO}$ ) up to $18.9 \mathrm{~mol} \%$, with remarkable correspondence between both $\mathrm{D}_{\mathrm{Me}}$ of

$6 \mathrm{Mn}$ and $\mathrm{Mg}$ (determined from bulk solid and aqueous phase analyses; Fig. 3), as well as the Mn

7 and $\mathrm{Mg}$ contents of high-Mg calcite cements (as determined by laser ablation ICP-MS; Fig. 3

8 inset). The base of this zone marks a subsequent increase in TOC.

\section{$10 \quad$ 4.2.3 Chemofacies III}

11 This zone is defined as being from the base of Chemofacies II to at least $30 \mathrm{~cm}$ depth. At the top,

12 bulk sediment concentrations of $\mathrm{Zn}$ and $\mathrm{Cd}$ are at their highest (Fig. 3). The top is also

13 characterized by mottled organic matter-rich zones and exhibits a local maximum in $\mathrm{Mo}$ and $\mathrm{Cu}$

14 concentrations. Chemofacies III shows relatively constant concentrations of Fe, which contrast

15 with the progressive depletion of solid-phase Mn. Nickel and cobalt rise above our instrumental

16 detection limits (Fig. 3) indicating that these elements may be dependent on the rates of Fe(III)

17 and $\mathrm{Mn}(\mathrm{IV})$-reduction. These trends are accompanied by increasing concentrations of $\mathrm{Cr}, \mathrm{V}$, and

$18 \mathrm{U}$ (not shown), whose geochemical behaviours are strongly correlated ( $\mathrm{r}_{\mathrm{S}}=0.84$ to $0.93, \mathrm{p}<$

19 0.001) with those of the redox sensitive element Re. This redox sensitive element increases

20 progressively towards the base, peaking at about $22 \mathrm{~cm}$ below the water-sediment interface. The

21 down core distribution of solid phase-bound Re allows for the identification of the most reducing

22 intervals. 
2 A buried microbial mat hosting a laminar dolomite-bearing horizon was observed at a depth

3 between 8 and $12 \mathrm{~cm}$ below the sediment water interface (Fig. 3). At this interval, the mineral

4 assemblage consists of halite, partially replaced gypsum, and aragonite. They are cemented by

\subsection{Ca-dolomite distribution}

microcrystalline high $\mathrm{Mg}$ calcite and disordered Ca-dolomite. The latter occurs interstitially as

spheroidal aggregates composed of sub-micrometer-scale rhombs that are in direct contact with decaying EPS (Fig. 5A). WDS analyses show that the proportion of $\mathrm{CaCO}_{3}$ in micritic $\mathrm{Ca}$ dolomite is between 57.8 to 60.1 wt. \% (Fig. 5B).

Changes in TOC (Fig. 3), total nitrogen (not shown), and $\mathrm{Mg}, \mathrm{Fe}$, and $\mathrm{Mn}$ concentrations depth profiles (Figs. 3, 5C), point to a link between heterotrophy, the bulk-sediment abundance of Ca-dolomite, and these elements. Also, within a chemostratigraphic context, it was observed that $\mathrm{Zn}, \mathrm{Mo}, \mathrm{Re}, \mathrm{Cu}$, and As are enriched immediately below the dolomite-cemented interval (see Fig. 3). The co-enrichment of siderophile and chalcophile metals at this level suggests coprecipitation with solid phase sulfide minerals, such as pyrite. However, neither pyrite nor its precursor monosulfide phases were observed, and if present, they were below the detection limit of standard XRD analyses ( 2 wt. \%). On this note, a closer observation to the bulk sediment concentration trends (Table 1) shows strong correlation $\left(\mathrm{r}_{\mathrm{S}}=0.907 \pm 0.030, \mathrm{p}<0.001\right)$ between chalcophile elements (e.g., Zn and Cd) with P, but not between these elements and Fe (Fig. 4). This result points to metal scavenging potential by another mineral phase, such as Cahydroxyapatite (e.g., Seaman et al., 2001). The latter occurs as small sub-millimeter-scale concretions below the dolomite-cemented interval (Fig. 6).

Petrographic relationships revealed by EPMA indicate that $S^{0}$ has accumulated in zones texturally dominated by gypsum and aragonite, while interstitial zones are being occluded by a 
1 mixture of microcrystalline Mg-enriched carbonate cements that lack $S^{0}$ accumulations (Fig. 5D).

2 In order to evaluate the association between Ca-dolomite, Mn accumulations and $\mathrm{S}^{0}$ depletion,

3 the solid phase chemostratigraphic data were complemented by a number of high resolution in

4 situ analyses, including LA-ICP-QMS, $\mu$ XRD, $\mu$ XRF and $\mu$ XANES. With a spatial resolution

5 (spot size diameter) of $40 \mu \mathrm{m}$, our laser ablation data shows a striking correlation between the

6 concentrations of $\mathrm{Mn}$ and $\mathrm{Mg}$ (see Fig. 3 inset). The integration of our $\mu$ XRD analyses with

$7 \mu \mathrm{XRF}$ (spatial resolution $=5 \times 6 \mu \mathrm{m}$ ) also reveals the co-occurrence of microcrystalline Ca-

8 dolomite $\left(\mathrm{d}_{104}=2.901 \AA\right)$, high-Mg calcite, and aragonite in association with solid phase

9 accumulations of manganese (Figs. 7, 8). Unfortunately, defining the exact mineralogy of Mn-

10 bearing phases is precluded by the poor crystallinity of the mineral phases comprising these

11 heterogeneous cements and their nanometer crystal size. Moreover, the presence of calcite makes

12 it difficult to detect small amounts of Mn(II)-bearing carbonate phases (cf. Table 2). It is

13 important to note that although thermodynamically predicted, no Ca-dolomite was positively

14 identified in sediments directly influenced by the decaying process of the surficial photosynthetic

15 microbial mat system. Indeed, in this peritidal parasequence, the mineral was only identified in

16 the suboxic zone influenced by the subsurface decay of a buried microbial mat

184.4 Evidence for multiple manganese redox states

19 Electron probe microanalyses demonstrate that the interstitial distribution of Ca-dolomite is

20 accompanied by a decrease in solid-phase sulfur (Fig. 5D). Synchrotron-based microanalyses, on

21 the other hand, reveal that Mn occurs in interstitial areas being occluded by heterogeneous

22 carbonate cements (Figs. 7, 8), and that other transition metals, known for their affinity for

23 reactive manganese species (e.g., $\mathrm{Ni}, \mathrm{Co}$, and $\mathrm{Zn}$ ), are spatially related with the $\mathrm{Mn}$ 
1 accumulations (Fig. 8; Table 3). XANES further provides information about the mineralogy of

2 the Mn-bearing phases, as well as the Mn redox states. The presence of $\mathrm{Mn}(\mathrm{III})$ is evident by the

3 position and broad white line feature of the K-edge, which exhibits two peaks at 6545.0 and

$4 \quad 6548.5 \mathrm{eV}$ (Fig. 9A,B). A linear combination fit of the sorption edge is only achieved by

5 including $\mathrm{Mn}_{2} \mathrm{O}_{3}, \mathrm{MnCO}_{3}, \mathrm{\gamma}-\mathrm{MnOOH}$, and $\mathrm{Mn}_{3} \mathrm{O}_{4}$ as standards (Fig. 9C). From the semi-

6 quantitative analysis of the resulting Mn-K edge spectrum it can be concluded that in the

7 dolomite-bearing interval, most manganese occurs interstitially as mixed-valence state oxide

8 minerals, yet a substantial fraction of reduced $\mathrm{Mn}^{2+}$ may substitute for $\mathrm{Mg}^{2+}$ in the micritic 9 carbonates.

$11 \quad 4.5$ Mn cycling as a factor promoting dolomite stabilization?

12 Several lines of evidence suggest that dolomite growth in the Francisqui lagoon was more likely 13 promoted by cycling of metals (specifically $\mathrm{Mn}$ ) as opposed to metabolisms more commonly 14 implicated in dolomite formation, such as sulfate reduction or methanotrophy. These include (1)

15 the strong correspondence between sedimentary $\mathrm{Mn}$ and $\mathrm{MgCO}_{3}$ enrichments throughout the 16 sedimentary pile, (2) tight correspondence between $\mathrm{Mg}$ and $\mathrm{Mn}$ contents in micrite cements in

17 the dolomite-cemented interval, and (3) the co-occurrence of elemental sulfur with $\mathrm{Mn}$ in 18 multiple valence states in the dolomitized interval. The dolomite cemented interval occurs at 19 significant depth $(8-12 \mathrm{~cm})$ below the sediment-water interface, it is restricted to the buried mat, 20 and is located well within the zone of sulfate reduction. These features all point towards the fact 21 that the nucleation of dolomite may not actually be occurring at present, but rather occurred as 22 the microbial mat hosting the dolomitized interval was buried. The strong correspondence 23 between $\mathrm{Mn}$ and $\mathrm{MgCO}_{3}$ in bulk sediments and micritic cements, combined with the presence of 
$1 \mathrm{Mn}$ in mixed valence states in the dolomite interval, suggest an important role for Mn cycling

2 during early diagenetic dolomite growth. Below we expand on the potential operation and

3 efficiency of Mn-driven diagenetic reactions that would act to favor dolomitization.

4 As in surface ocean waters, most dissolved manganese in the lagoon is thought to be 5 maintained in its divalent state (i.e., Sunda and Huntsman, 1988, 1990) due to its slow oxidation

6 rate in the presence of $\mathrm{O}_{2}$ (Murray and Brewer, 1977). Therefore, $\mathrm{Mn}^{2+}$ may potentially form

7 organo-metallic complexes with reactive ligands of the microbial mat (i.e., Petrash et al., 8 2011a,b). Nonetheless, Mn(II)-oxidizing bacteria could be highly active under conditions of low 9 oxygen, as shown in other hypersaline systems (e.g., Tebo, 1991). Previous work has also shown 10 that both $\mathrm{Mn}_{3} \mathrm{O}_{4}$ and $\mathrm{MnOOH}$ are the primary products of enzyme-catalyzed $\mathrm{Mn}$ (II) oxidation 11 reactions (Hasting and Emerson, 1986; Mann et al., 1988; Bargar et al., 2000). These phases may 12 then transform into $\mathrm{Mn}(\mathrm{IV})$ oxides abiotically, via the autocatalytic oxidation of $\mathrm{Mn}$ (III), leading 13 to disproportionation (Bargar et al., 2000; Tebo et al. 2004). Nucleation of both primary and 14 secondary Mn-bearing oxide phases may also be catalyzed by organic and inorganic ligands 15 comprising microbial mats (i.e., Haack and Warren, 2003). The rapid burial of reactive microbial 16 mats in peritidal settings can thus enable a cascade of aqueous reactions involving intermediate 17 and reduced forms of manganese and sulfur that allow the metal to be recycled multiple times 18 (Fig. 10). Upon burial, the Mn (oxy)hydroxide phases within the EPS may become solubilized.

20 After oxygen (and nitrate if available) is consumed, the earliest stage of anaerobic respiration in 21 the sedimentary pile involves the progressive reduction of Mn (oxy)hydroxides to soluble $\mathrm{Mn}$ (II)

22 (Burdige and Nealson, 1985; Burdige, 1993, Tebo et al., 2004). This dissolved Mn(II) may 23 influence local mineral saturation with respect to Mn-bearing carbonates (e.g., cf. Mucci, 1988), 
1 or may diffuse vertically and/or laterally, to be biologically oxidized back to Mn(IV), sometimes

2 accompanied by the formation of solid phase and potentially mixed-valence Mn oxides,

3 including Mn(III)-bearing intermediates (Burdige and Nealson, 1985; Myers and Nealson, 1988;

4 Calvert and Pedersen, 1996; Tebo et al., 2004; Tribovillard et al., 2006; Trouwborst et al., 2006).

5 When the process is linked to reduced and intermediate sulfur species (e.g., $\mathrm{HS}^{-}, \mathrm{S}^{0}$ ), the

6 formation of $\mathrm{Mn}$ (oxy)hydroxides promotes reactions that evolve pore-waters towards more

7 alkaline conditions. Indeed, Aller and Rude (1988) demonstrated that in normal marine-derived

8 pore-waters, most alkalinity produced during the reduction of $\mathrm{Mn}(\mathrm{IV})$ is rapidly consumed by the

9 co-precipitation of $\mathrm{Ca}$, and some of the reduced $\mathrm{Mn}(\mathrm{II})$, into $\mathrm{Mg}$-rich calcites.

10 Here we suggest that Mn(IV) reduction and recycling may also lead to the precipitation

11 of Ca-dolomite. In our model, the precipitation potential of dolomite is enhanced by the co-

12 occurrence of reduced sulfur species (e.g., $\mathrm{HS}^{-}, \mathrm{S}^{0}$ ) and Mn (oxy)hydroxides within the buried

13 microbial mat, i.e., the dolomite-cemented interval. This occurs during reduction of Mn(IV/III)

14 coupled to sulfur oxidation (reactions 1-2) or during $\mathrm{Mn}(\mathrm{III})$-driven elemental sulfur

15 disproportionation (reaction 3) (Thamdrup et al., 1993; Böttcher and Thamdrup 2001; Schippers

16 and Jørgensen, 2001). Moreover, Mn(III) species produced during sulfide oxidation (e.g.,

17 reaction 1) are more active in sedimentary diagenesis than previously thought because they can

18 also act as an electron donor (reaction 4) (Trouwborst et al., 2006; Madison et al., 2013).).

$192 \mathrm{MnO}_{2}+\mathrm{HS}^{-}+\mathrm{H}_{2} \mathrm{O} \rightarrow 2 \mathrm{MnOOH}+\mathrm{S}^{0}+\mathrm{OH}^{-}\left(\Delta \mathrm{G}_{\mathrm{r}}=-96 \mathrm{~kJ} / \mathrm{mol}\right),(1)$

$20 \quad 3 \mathrm{MnO}_{2}+\mathrm{S}^{0}+2 \mathrm{H}_{2} \mathrm{O} \rightarrow \mathrm{SO}_{4}{ }^{2-}+3 \mathrm{Mn}^{2+}+4 \mathrm{OH}^{-}\left(\Delta \mathrm{G}_{\mathrm{r}}=-107 \mathrm{~kJ} / \mathrm{mol}\right),(2)$

$21 \mathrm{Mn}_{3} \mathrm{O}_{4}+3 \mathrm{~S}^{0}+2 \mathrm{H}^{+} \rightarrow 3 \mathrm{Mn}^{2+}+\mathrm{SO}_{4}{ }^{2-}+2 \mathrm{HS}^{-}\left(\Delta \mathrm{G}_{\mathrm{r}}=-118 \mathrm{~kJ} / \mathrm{mol}\right),(3)$

$222 \mathrm{MnOOH}+2 \mathrm{H}^{+} \rightarrow \mathrm{MnO}_{2}+\mathrm{Mn}^{2+}+2 \mathrm{H}_{2} \mathrm{O}\left(\Delta \mathrm{G}_{\mathrm{r}}=-51 \mathrm{~kJ} / \mathrm{mol}\right)$. (4) 
These redox reactions are relevant in suboxic near-shore sediments where intermediate

2 and reduced sulfur species are brought into close contact with Mn (oxy)hydroxides by natural

3 depositional or syndiagenetic processes (Aller, 1990). They collectively act to increase total

4 alkalinity (see Aller and Rude, 1988), and as experimentally demonstrated by Böttcher and

5 Thamdrup (2001), also lead to a continuous increase in $\mathrm{pH}$ (e.g., reactions 1-4). However, for

6 dolomite saturation, equally or perhaps even more important is their role in recycling $\mathrm{Mn}$ and

7 assuring for a steady upwards diffusive supply and continual oxidation of $\mathrm{Mn}^{2+}$. This, in turn,

8 yields $\mathrm{Mn}(\mathrm{IV})$ oxides that can be reduced anew to sustain long-term conditions that — because of

9 the high $\mathrm{Mg} / \mathrm{Ca}$ ratios of the precipitation microenvironment - may be favorable for dolomite

10 growth. Importantly, our semi-quantitative XANES analyses showed that although some of the

$11 \mathrm{Mn}^{2+}$ diffuses upwards where it could be re-oxidized, a fraction of it substitutes for $\mathrm{Mg}$ into

12 newly formed Ca-dolomite (cf. Fig. 9), leaving the imprint of Mn cycling that we believe we are

13 observing in the dolomite cemented interval at Francisqui lagoon. Using published Mn

14 partitioning coefficients $\left(\mathrm{K}_{\mathrm{D}}\right)$ for carbonates in the rhodochrosite-calcite solid solution series

15 (Mucci, 1988; Böttcher, 1998), we estimate maximal pore-water Mn concentrations during

16 carbonate mineral precipitation at between 50 and 700 micromolar (depending on the $\mathrm{K}_{\mathrm{D}}$ ), which

17 fall within the range observed in Mn carbonate-rich sediments where Mn cycling dominates the

18 pore-water alkalinity budget (e.g., Thamdrup and Dalsgaard, 2000).

When coupled to the utilization of sedimentary organic matter (e.g., from the buried

20 microbial mat), $\mathrm{Mn}(\mathrm{IV})$ reduction (reaction 5) is more efficient than acetoclastic bacterial sulfate

21 reduction (BSR) at generating alkalinity (reaction 6). In the presence of intermediate forms of

22 sulfur, the process may continuously consume protons to sustain elevated $\mathrm{pH}$ levels in the 
1 precipitation environment. Such precipitation conditions have long been thought required for

2 interstitial dolomite nucleation (Lippmann, 1973; Middelburg et al., 19911990; Mazzullo, 2000).

$3 \mathrm{CH}_{3} \mathrm{COO}^{-}+4 \mathrm{MnO}_{2}+3 \mathrm{H}_{2} \mathrm{O} \rightarrow 4 \mathrm{Mn}^{2+}+2 \mathrm{HCO}_{3}^{-}+7 \mathrm{OH}^{-}\left(\Delta \mathrm{G}_{\mathrm{r}}=-569 \mathrm{~kJ} / \mathrm{mol}\right),(5)$

$4 \mathrm{CH}_{3} \mathrm{COO}^{-}+\mathrm{SO}_{4}{ }^{2-}+\mathrm{H}_{2} \mathrm{O} \rightarrow \mathrm{H}_{2} \mathrm{~S}+2 \mathrm{HCO}_{3}^{-}+\mathrm{OH}^{-} \quad\left(\Delta \mathrm{G}_{\mathrm{r}}=-48 \mathrm{~kJ} / \mathrm{mol}\right) .(6)$

A key point in this regard is whether or not the relatively low Mn concentrations

6 characterizing most marine sediments are capable of generating sufficient alkalinity as to locally

7 influence carbonate mineral saturation. Previous data for atypical marine sediments where

$8 \mathrm{Mn}(\mathrm{IV})$, rather than sulfate, serves as the primary terminal electron acceptor for anaerobic

9 respiration indicates that very little $\mathrm{Mn}$ is required. For example, Canfield et al. (1993a,b)

10 demonstrated that in Danish sediments with solid-phase Mn concentrations roughly two orders of

11 magnitude higher than reported herein, Mn(IV) was more important for respiration, and by proxy

12 the alkalinity budget, than all other electron acceptors combined, including oxygen, by a factor

13 of $~ 10$. In this environment, $\mathrm{Mn}(\mathrm{IV})$ reduction accounts for $25-99 \%$ of anaerobic carbon

14 oxidation in the upper $10 \mathrm{~cm}$ of sediments. Part of the reason is rampant $\mathrm{Mn}$ recycling; $\mathrm{Mn}(\mathrm{IV})$ is

15 continually regenerated by either spontaneous disproportionation of $\mathrm{Mn}(\mathrm{III})$ or by aerobic

16 oxidation of $\mathrm{Mn}(\mathrm{II})$, the latter being the product of $\mathrm{Mn}(\mathrm{IV})$ reduction and also $\mathrm{Mn}(\mathrm{III})$

17 disproportionation (see reactions 1-4; Fig. 10). In this manner, seemingly small sedimentary Mn

18 enrichments may have contributed to the general underestimation of the role of $\mathrm{Mn}$ in organic

19 matter cycling (cf. Canfield et al., 1993a; Sunda and Kieber, 1994), and thus alkalinity 20 generation.

21 Based on our observations at this novel dolomite-forming site, we speculate that in

22 peritidal settings the burial of metal-reactive microbial mats may act as a barrier capable of

23 localizing upward diffusing species in an autocatalytic feedback between Mn (oxy)hydroxide 
1 precipitation, solid phase sulfide dissolution, and carbon turnover (Fig. 10). While we consider

2 adsorption of $\mathrm{Mn}$ to the reactive mat substrate (promoting greater Mn residence times in the

3 suboxic manganic zone) a microbially-influenced process (cf. Dupraz et al., 2009), we consider

4 Ca-dolomite formation in this setting effectively a microbially-induced process (cf. Dupraz et al.,

5 2009), whereby the initial standing stock of reactive manganese and its efficient redox cycling

6 sustain the elevated alkalinities promoting Ca-dolomite growth. Importantly, as this biochemical

7 process takes place, the rapid oxidation of diffused $\mathrm{HS}^{-}$(reaction 1) may also act to alleviate the

8 inhibitory effect of $\mathrm{Mg}$ coordination by water at the solution-solid interface (see Zhang et al.,

9 2012, and also Yang et al. 2012), and ultimately facilitate interstitial Ca-dolomite growth. It is

10 important to also note that abundant Mn cycling is not likely sufficient on its own; higher initial

11 dissolved $\mathrm{Mg} / \mathrm{Ca}$, such as occurs in Francisqui lagoon ( 6.1), is likely important in that it

12 kinetically favors the formation of Ca-dolomite.

13 The influence of the water activity $\left(a_{\mathrm{w}}\right)$ on the crystallization of Mg-rich carbonates may

14 also be important for the precipitation of dolomite precursors. In experiments where this effect

15 has been tested (i.e., at $a_{\mathrm{w}}$ below the life limit, $<0.72$ ), the resulting solid phases are a mixture of

16 magnesian calcite, aragonite, and hydromagnesite, but no dolomite (e.g., Lenders et al., 2012;

17 Radha et al., 2012). The hydrated Mg oxides in such experiments attest to the strong binding of

18 the first hydration shell to Mg. In hypersaline systems where the activity of water does not

19 prevent the growth of microbial life, hydrated $\mathrm{Mg}$ oxides are only found in supratidal zones at

20 very high evaporation rates. In such environments, the removal of $\mathrm{Ca}^{2+}$ due to the precipitation

21 of gypsum $\left(\mathrm{CaSO}_{4} \cdot 2 \mathrm{H}_{2} \mathrm{O}\right)$ contributes to a rise in pore waters $\mathrm{Mg} / \mathrm{Ca}$ ratios. It also consumes

22 sulfate from the water column, making it available as an electron acceptor in subsequent shallow

23 burial diagenetic reactions (i.e., Petrash et al., 2012). Gypsum reduction also facilitates 
1 dolomitization because it creates high alkalinity via the oxidation of the sedimentary organic

2 matter, and the carboxylic acids liberated can serve as nucleation templates (Roberts et al., 2013;

3 Kenward et al., 2013).

4 The high dissolved $\mathrm{Mg} / \mathrm{Ca}$ ratios in our study site clearly favors the precipitation of $\mathrm{Mg}$ -

5 rich carbonate, but not Mn-rich carbonate-bearing phases, which are more common in sediments

6 exposed to relatively low open marine $\mathrm{Mg} / \mathrm{Ca}$ ratios and much higher $\mathrm{Mn}$ concentrations.

7 Because the mechanism for sustained alkalinity described here would coincide with a zone of

8 relatively high dissolved sulfide concentrations, it is possible that some of the early microbial

9 models ascribing a prominent role to BSR might in fact be much more complicated and involve

10 Mn (and S) cycling. As recently suggested by Meister (2013), BSR alone might be ineffective

11 for inducing carbonate saturation (but see Gallagher et al., 2012), and only with an alternative

12 mechanism acting in parallel would BSR lead to a state of localized dolomite supersaturation

13 (i.e., Moreira et al., 2004).

\section{6. Summary and conclusions}

16 At Francisqui, a buried microbial mat appears to have facilitated authigenic dolomite 17 precipitation in three ways: (1) by providing a highly reactive substrate for initial $\mathrm{Mn}$ and $\mathrm{Mg}$

18 sorption, (2) by providing the reducing equivalents (as organic carbon) for driving heterotrophic

19 reactions that promote alkalinity and carbonation of $\mathrm{Mg}$ ions, and (3) upon rapid burial, bringing

20 the Mn-rich, diffusion-limited mat substrate into the sulfate reduction zone where coupled Mn-S

21 redox cycling auto-catalytically enhanced alkalinity generation given sufficient organic matter.

22 We suggest here that these process have the potential to locally increase $\mathrm{pH}$ and alkaline

23 conditions, which together with relatively high $\mathrm{Mg}$ :Ca ratios observed in the lagoon water and 
1 inferred for the pore-waters, fulfills the prerequisites for the interstitial stabilization (and growth)

2 of early formed dolomite precursors in shallow burial diagenetic realms. More detailed studies

3 on classic penecontemporaneous dolomite-forming settings should consider the importance of

4 manganese cycling in dolomite authigenesis and the integral role of subsurface microbes in

5 shallow burial dolomite formation.

6

7 Acknowledgments

8 The authors wish to thank three anonymous reviewers who provided constructive criticisms and

9 comments that greatly improved this manuscript, and to Dr. Michael E. Böttcher for editorial

10 handling. Funds for this research were provided by the National Science and Engineering

11 Research Council of Canada (NSERC) granted to K.O.K. S.V.L acknowledges support from

12 NSERC and LabexMER. PNC/XSD facilities at the Advanced Photon Source, and research at

13 these facilities, are supported by the US Department of Energy - Basic Energy Sciences, a Major

14 Resources Support grant from NSERC, the University of Washington, the Canadian Light

15 Source and the Advanced Photon Source. Use of the Advanced Photon Source, an Office of

16 Science User Facility operated for the U.S. Department of Energy (DOE) Office of Science by

17 Argonne National Laboratory, was supported by the U.S. DOE under Contract No. DE-AC02-

18 06CH11357. We also thank Dr. Lachlan McLean, Dr. Ferenc Borondics (and the team members

19 of the mid-IR (01B1-1) beamline) at the Canadian Light Source for technical advice and support,

20 as well as Dr. François Orange for his support with TEM.

\section{References}

22 Aller R. C., 1990. Bioturbation and manganese cycling in hemipelagic sediments. Philosophical 
1 Aller, R. C., 1994. The sedimentary Mn cycle in Long Island Sound. Its role as intermediate oxidant and the influence of bioturbation, $\mathrm{O}_{2}$, and $\mathrm{C}_{\mathrm{org}}$ flux on diagenetic reaction balances. J.Marine Research, 52, 259-295.

Aller, R.C., and Rude, P.D., 1988. Complete oxidation of solid phase sulfides by manganese and bacteria in anoxic marine sediments. Geochimica et Cosmochimica Acta 52, 751-765.

Arvidson, R.S., MacKenzie, F.T., 1999. The dolomite problem: control of precipitation kinetics by temperature and saturation state. Amer. J. Sci. 299, 257-288.

Ball, J.W., and Nordstrom, K., 1991. User's manual for WATEQ4F, with revised thermodynamic data base and test cases for calculating speciation of major, trace, and redox elements in natural waters. U.S. Geological Survey Open-File Report 91-183.

Bargar, J., Tebo, B., Villinski, J., 2000. In situ characterization of Mn (II) oxidation by spores of the marine Bacillus sp. strain SG-1. Geochimica et Cosmochimica Acta 64, 2775-2778

Braissant, O., Decho, A. W., Dupraz, C., Glunk, C., Przekop, K. M., and Visscher, P. T., 2007. Exopolymeric substances of sulfate-reducing bacteria: Interactions with calcium at alkaline $\mathrm{pH}$ and implication for formation of carbonate minerals. Geobiology 5, 401-11.

Braissant, O., Decho, A.W., Przekop, K.M., Gallagher, K.L., Glunk, C., Dupraz, C., and Visscher, P.T., 2009. Characteristics and turnover of exopolymeric substances in a hypersaline microbial mat. FEMS Microbial. Ecol.67, 2005-2008.

Breuker, A., Stadler, S., and Schippers, A., 2013. Microbial community analysis of deeply buried marine sediments of the New Jersey shallow shelf, IODP Expedition 313. FEMS Microbial. Ecol., doi. 10.1111/1574-6941.12146 
1 Böttcher, M., and Thamdrup, B., 2001. Anaerobic sulfide oxidation and stable isotope fractionation associated with bacterial sulfur disproportionation in the presence of $\mathrm{MnO}_{2}$. Geochimica et Cosmochimica Acta 65, 1573-1581.

4 Boyanov, M.I., Kelly, S.D., Kemner, K.M., Bunker, B.A., Fein, J.B., and Fowle, D.A., 2003. Adsorption of cadmium to Bacillus subtilis bacterial cell walls: A pH-dependent X-ray absorption fine structure spectroscopy study. Geochimica et Cosmochimica Acta 67, 3299-3311.

Burdige, D.J., 1993. The biogeochemistry of manganese and iron reduction in marine sediments. Earth-Science Reviews 35, 249-284.

Burdige, D. J., and Nealson, K. H., 1985. Microbial manganese reduction by enrichment cultures from coastal marine sediments. Applied Environ. Microbiol. 50, 491-7.

Calvert, S. E., and Pedersen, T. F., 1996. Sedimentary Geochemistry of Manganese: Implications for the Environment of Formation of Manganiferous Black Shales. Econ. Geol. 91, 3647.

Canfield, D. E., Thamdrup, B., and Hansen, J. W., 1993a. The anaerobic degradation of organic matter in Danish coastal sediments: Iron reduction, manganese reduction, and sulfate reduction. Geochimica et Cosmochimica Acta 57, 3867-83.

Canfield, D.E., Jørgensen, B.B., Fossing, H., Glud, R., Gundersen, J., Ramsing, N.B., Thamdrup B., Hansen J.W., Nielsen L.P., Hall P.O.J., 1993b. Pathways of organic carbon oxidation in three continental margin sediments. Marine Geology 113, 27-40.

Castanier, S., Métayer-Levrel, G. Le, and Perthuisot, J., 1999. Ca-carbonate precipitation and limestone genesis —-the microbiogeologist point of view. Sed.Geol.126, 9-23 
1 Compton, J., 1992. Early diagenesis and the origin of diagenetic carbonate in sediment recovered

from the Argo Basin, Northeastern Indian Ocean, Site 765. Proceedings of the Ocean Drilling Program, Site 765, 77-88.

Covington, A.K., Whitfield, M., 1988. Recommendations for the determination of $\mathrm{pH}$ in sea water and estuarine waters. Pure Appl. Chem. 60, 865-870.

Curtis, C.D., Cope, J.C.W., Plant, D., and Macquaker, J.H.S., 2000. "Instantaneous" sedimentation, early microbial sediment strengthening and a lengthy record of chemical diagenesis preserved in Lower Jurassic ammonitiferous concretions from Dorset. $J$. Geol.Soc. 157, 165-72.

Davies, P., Ferguson, J, and Bubela, B., 1975. Dolomite and organic material. Nature 255, 47274.

Decho, A.W., 2000. Microbial biofilms in intertidal systems: an overview. Continental Shelf Research 20, 1257-1273.

Decho, A. W., Visscher, P. T., and Reid, R. P., 2005. Production and cycling of natural microbial exopolymers, EPS, within a marine stromatolite. Palaeogeog., Palaeoclim., Palaeoecol. $219,71-86$

Défarge, C., Trichet, J., Jaunet, A.M., Robert, M., and Sansone, F.J., 1996. Texture of microbial sediments revealed by cryo-scanning electron microscopy. J. Sed. Research 66, 935-47.

Demicco, R.V., and Hardie, L.A., 1994. Sedimentary structures and early diagenetic features of shallow marine carbonate deposits, Atlas 1. SEPM, 265 p.

Des Marais, D. J., 2003. Biogeochemistry of hypersaline microbial mats illustrates the dynamics of modern microbial ecosystems and the early evolution of the biosphere. The Biological Bulletin 204, 160-167. 
1 Drever, J. I., 1988. The geochemistry of natural waters (2nd ed.). Englewood Cliffs, New Jersey, $2 \quad$ Prentice-Hall, 437 p.

3 Dupraz, C., Reid, R.P., Braissant, O., Decho, A.W., Norman, R.S., Visscher, P.T., 2009.

4 Processes of carbonate precipitation in modern microbial mats. Earth Science Reviews $596,141-162$.

6 Fein, J., Daughney, C., Yee, N., and Davis, T., 1997. A chemical equilibrium model for metal adsorption onto bacterial surfaces. Geochimica et Cosmochimica Acta 61, 3319-3328.

8 Filzmoser, P., and Hron, K. 2008. Outlier detection for compositional data using robust methods. $9 \quad$ Mathematical Geoscience. 40, 233-248.

10 Fraústo da Silva, J.J.R.,Williams, R.J.P., 2001. The Biological Chemistry of the Elements, 11 second ed. Oxford University Press, Oxford, UK, 575 pp.

12 Froelich, P.N., Klinkhammer, G.P., Bender, M.L., Luedtke, N.A., Heath, G.R., Cullen, D., 13 Dauphin, P., Hammond, D., Hartman, B., and Maynard, V., 1979. Early oxidation of 14 organic-matter in pelagic sediments of the eastern equatorial Atlantic: Suboxic 15 diagenesis: Geochimica et Cosmochimica Acta 43, 1075-1090.

16 Gallagher, K.L., Kading, T.J., Braissant, O., Dupraz, C., and Visscher, P.T., 2012. Inside the 17 alkalinity engine: the role of electron donors in the organomineralization potential of 18 sulfate-reducing bacteria. Geobiology 10, 518-30.

19 Gebelein, C.D., and Hoffman, P., 1973. Algal origin of dolomite laminations in stromatolitic limestone. Journal of Sedimentary Petrology 43, 603-613.

21 Geesey, G.G., and Jang, L., 1989. Interactions between metal ions and capsular polymers. In 22 Beveridge, T.J., and Doyle R., eds., Metal ions and bacteria, 325-357. 
1 Gilbert, P., Abrecht, M., and Frazer, B.H., 2005. The organic-mineral interface in biominerals. Reviews in Mineralogy and Geochemistry 59, 157-185.

3 Glew, J.R., 1991. Miniature gravity corer for recovering short sediment cores. Journal of $4 \quad$ Paleolimnology 5, 285-287

5 Haack, E.A., Warren, L.A., 2003. Biofilm Hydrous Manganese Oxyhydroxides and Metal Dynamics in Acid Rock Drainage. Environ. Sci. Technol. 37, 4138-4147.

7 Hammersley A.P., Svensson, S.O., Han, M., Fitch A.N., and Hausermann D., 1996. Twodimensional detector software: from real detector to idealized image or two-theta scan: High Pressure Research 14, 235-248.

Hardie, L.A., and Shinn, E.A., 1986. Carbonate depositional environments - modern and ancient - part 3. tidal flats. Colorado School of Mines Quarterly 81, 1-74.

12 Jones, B., Luth, R., and MacNeil, A., 2001. Powder X-ray diffraction analysis of homogeneous and heterogeneous sedimentary dolostones. Journal of Sedimentary Research 71, 790-

Kendall, C.G.St.C., and Skipwith P.S. 1968. Recent algal mats of a Persian Gulf lagoon. Journal 799.

17 Kenward, P., and Goldstein, R., 2009. Precipitation of low-temperature dolomite from an anaerobic microbial consortium: the role of methanogenic Archaea. Geobiology 7, 556565.

Kenward, P., Fowle, D. A., Goldstein, R.H., Ueshima, M., González, L.A., and Roberts, J. A., 2013. Ordered low-temperature dolomite mediated by carboxyl-group density of microbial cell walls. AAPG Bulletin 97, 2113-2125. 
1 Konhauser, K.O., Fisher, Q.J., Fyfe, W.S., Longstaffe, F.J., and Powell, M.A., 1998. Authigenic mineralization and detrital clay binding by freshwater biofilms: The Brahmani River, India. Geomicrobiology Journal 15, 209-222.

4 Konhauser, K.O. 2007. Introduction to Geomicrobiology. Blackwell Publishing. 433 p.

5 Kraft, S., Stümpel, J., Becker, P., Kuetgens, U. 1996. High resolution x-ray absorption spectroscopy with absolute energy calibration for the determination of absorption edge energies. Review of scientific instruments 67, 681-687.

Kwak, S. Y., DiMasi, E., Han, Y.-J., Aizenberg, J., and Kuzmenko, I., 2005. Orientation and Mg Incorporation of Calcite Grown on Functionalized Self-Assembled Monolayers. A Synchrotron X-ray Study. Crystal Growth and Design 5, 2139-2145.

Lalonde, S.V., Konhauser, K.O., Reysenbach, A.-L., and Ferris, F.G., 2005. Thermophilic silicification: The role of Aquificales in hot spring sinter formation. Geobiology 3, 41-52.

Lalonde, S.V., Amskold, L, McDermott, T.R., Inskeep, W.P., and Konhauser, K.O., 2007. Chemical reactivity of microbe and mineral surfaces in hydrous ferric oxide depositing hydrothermal springs. Geobiology 5, 219-234.

Lalonde, S.V., Dafoe, L.T., Pemberton, S.G., Gingras, M.K., and Konhauser, K.O., 2010. Investigating the geochemical impact of burrowing animals: Proton and cadmium adsorption onto the mucus lining of Terebellid polychaete worms. Chemical Geology $271,44-51$.

Lenders, J.J.M., Dey, A., Bomans, P.H.H., Spielmann, J., Hendrix, M.M.R.M., de With, G., Meldrum, F.C., Harder, S., Sommerdijk, N.A.J.M., With, G. De, 2012. High-Magnesian Calcite Mesocrystals: A Coordination Chemistry Approach. J. Am. Chem. Soc. 134, 
1367-73. Lippmann, F., 1973. Sedimentary carbonate minerals. Berlin, Springer-Verlag, 228

Madison, A.S., Tebo, B.M., Mucci, A., Sundby, B., and Luther, G.W. 2013. Abundant porewater Mn (III) is a major component of the sedimentary redox system. Science 341, 875878.

Manceau, A., Marcus, M., and Grangeon, S., 2012. Determination of Mn valence states in mixed-valent manganates by XANES spectroscopy. American Mineralogist 97, 816-827.

Mann, S., Sparks N.H.C., Scott, G.H.E., and deVrind-deJong E.W., 1988. Oxidation of manganese and formation of $\mathrm{Mn}_{3} \mathrm{O}_{4}$ (hausmannite) by spore coats of a marine Bacillus sp. Applied Environmental Microbiology 54, 2140-2143.

Mazzullo, S.J., 2000, Organogenic Dolomitization in Peritidal to Deep-Sea Sediments. J. Sed. Research 70, 10-23.

Meister, P., 2013. Two opposing effects of sulfate reduction on carbonate precipitation in normal marine, hypersaline, and alkaline environments. Geology 41, 499-502.

Middelburg, J., de Lange, G.J., and Kreulen, R., 1990. Dolomite formation in anoxic sediments of Kau Bay, Indonesia. Geology 18, 399-492

Montero-Serrano, J.C., Palarea-Albaladejo, J., Martín-Fernández, J.A., Martínez-Santana, M., and Gutiérrez-Martín, J. V.,2010. Sedimentary chemofacies characterization by means of multivariate analysis. Sedimentary Geology 228, 218-228.

Moreira, N.F., Walter, L.M., Vasconcelos, C., McKenzie, J.A., and Mccall, P.J., 2004. Role of sulfide oxidation in dolomitization: sediment and pore-water geochemistry of a modern hypersaline lagoon system. Geology 32, 701-704. 
1 Mucci, A., 1988. Manganese uptake during calcite precipitation from seawater: conditions leading to the formation of a pseudokutnahorite. Geochimica et Cosmochimica Acta 52, $1859-1868$.

Murray, J.W. and Brewer, P.G., 1977. Mechanism of removal of manganese, iron and other trace metals from seawater, in: Glasby, G.P., ed., Marine manganese deposits. Elsevier, Amsterdam, 291- 325.

Myers, C. R., and Nealson, K.H., 1988. Microbial reduction of manganese oxides. Interactions with iron and sulfur. Geochimica et Cosmochimica Acta 52, 2727-2732.

Nordstrom, D.K., Plummer, L.N., Langmuir, D., Busenberd, E, May, H. M., Jones, B.F., and Parkhurst, D.L., 1990, Revised chemical equilibrium data for major water-mineral reactions and their limitations, in Melchior, D. C, and Bassett, R. L., eds., Chemical modeling of aqueous systems II: American Chemical Society Symposium Series 416, 398413.

Petrash, D.A., Gingras, M., and Lalonde, S.V., Orange, F., Pecoits, E., and Konhauser, K.O., 2012. Dynamic controls on accretion and lithification of modern gypsum-dominated thrombolites, Los Roques, Venezuela. Sedimentary Geology 245-246, 29-47.

Petrash, D.A., Lalonde, S.V., Raudsepp, M., Konhauser, K.O. 2011a. Assessing the importance of organic matrix materials in biofilm chemical reactivity: insights from proton and cadmium adsorption onto the commercially available biopolymer alginate. Geomicrobiology Journal 28, 266-273

Petrash, D.A., Lalonde, S.V., Gingras, M.K., and Konhauser, K.O., 2011b. A surrogate approach to studying the chemical reactivity of burrow mucous linings in marine sediments. Palaios 26, 594-600. 
1 Ravel B. and Newville M., 2005, Athena, Artemis, Hephaestus: data analysis for X-ray absorption spectroscopy using IFEFFIT: J. Synchrotron Rad. 12, 537-541.

3 Raz, S., Weiner, S., and Addadi, L., 2000. Formation of High-Magnesian Calcites via an 4 amorphous precursor phase: possible biological implications. Advanced Materials 12, $38-42$.

6 Radha, A. V, Fernandez-martinez, A., Hu, Y., Jun, Y., Waychunas, G.A., Navrotsky, A., 2012.

$7 \quad$ Energetic and structural studies of amorphous Ca1?xMgxCO3?nH2O(0 6 x 6 1) A.V. 90, 83-95.

9 Roberts, J. A, Kenward, P. A, Fowle, D. A, Goldstein, R.H., González, L. A, and Moore, D.S., 2013. Surface chemistry allows for abiotic precipitation of dolomite at low temperature.

12 Sánchez-Román, M., Mckenzie, J.A., de Luca Rebello, A., Rivadeneyra, M.A., and Vasconcelos, C., 2009, Presence of sulfate does not inhibit low-temperature dolomite precipitation.

Schippers, A., and Jørgensen, B., 2001. Oxidation of pyrite and iron sulfide by manganese Earth and Planetary Science Letters 285, 131-139.

17 Seaman, J. C., Arey, J. S. and Bertsch, P. M., 2001. Immobilization of nickel and other metals in contaminated sediments by hydroxyapatite addition. J. Environ. Qual.30, 460-469.

19 Slaughter, M., Hill, R.J., 1991. The influence of organic matter in organogenic dolomitization. J. Sediment. Petrol. 61, 296-303.

21 Solé, V.A. Papillon, E. Cotte, M. Walter Ph., Susini, J. 2007, A multiplatform code for the analysis of energy-dispersive X-ray fluorescence spectra: Spectrochim. Acta Part B 62, 63-68. 
1 Sunda, W.G. Huntsman, S.A., 1988. Effect of sunlight on redox cycles of manganese in the southwestern Sargasso Sea. Deep-Sea Res. 35, 1297-1317.

3 Sunda, W.G. Huntsman, S.A., 1990. Diel cycles in microbial manganese oxidation and manganese redox speciation in coastal waters of the Bahama Islands. Limnol. Oceanogr. $35,325-328$.

Sunda, W.G., Kieber, D.J., 1994. Oxidation of humic substances by manganese oxides yields low-molecular-weight organic substrates. Nature 367, 62-64

Tebo, B.M., 1991. Manganese(II) oxidation in the suboxic zone of the Black Sea. Deep-Sea Research 38 (Suppl. 2), S883-S905

Tebo, B. M., Bargar, J. R., Clement, B. G., Dick, G. J., Murray, K. J., Parker, D., Verity, R., and Webb, S.M., 2004. Biogenic Manganese Oxides: Properties and Mechanisms of Formation. Annual Rev. Earth Planet. Sci.32, 287-328.

Thamdrup, B, and Finster, K., 1993. Bacterial disproportionation of elemental sulfur coupled to chemical reduction of iron or manganese. Applied Environ. Microbiol. 59, 101-108.

Thamdrup, B, Rosselló-Mora, R., and Amann, R., 2000. Microbial manganese and sulfate reduction in Black Sea shelf sediments. Applied Environ. Microbiol. 66, 2888-2897.

Thamdrup, B., Fossing, H., and Jørgensen, B., 1994. Manganese, iron and sulfur cycling in a coastal marine sediment, Aarhus Bay, Denmark. Geochimica et Cosmochimica Acta 58, $5115-29$.

Tribovillard, N., Algeo, T. J., Lyons, T., and Riboulleau, A., 2006. Trace metals as paleoredox and paleoproductivity proxies: An update. Chemical Geology 232, 12-32.

Trouwborst, R. E., Clement, B. G., Tebo, B. M., Glazer, B. T., and Luther, G. W., 2006. Soluble Mn, III, in suboxic zones. Science 313, 1955-57. 
1 Van Lith, Y., Warthmann, R., Vasconcelos, C., and McKenzie, J. A., 2003. Sulphate-reducing bacteria induce low-temperature Ca-dolomite and high Mg-calcite formation. Geobiology $1,71-79$.

Vasconcelos, C., McKenzie, J.A., Bernasconi, S., Grujic, D., and Tien, A.J., 1995, Microbial mediation as a possible mechanism for natural dolomite formation at low temperatures: Nature 377, 220-222.

Vasconcelos, C. and McKenzie, J. A., 1997. Microbial mediation of modern dolomite precipitation and diagenesis under anoxic conditions (Lagoa Vermelha, Rio De Janeiro, Brazil). J. Sed. Research 67, 378-390.

Visscher, P. T., and Stolz, J. F., 2005. Microbial mats as bioreactors: populations, processes, and products. Palaeogeog., Palaeoclim., Palaeoecol. 219, 87-100.

Von der Borch, C.C., and Lock, D., 1979. Geological significance of Coorong dolomites: Sedimentology 26, 813-824.

Wang, D., Wallace, A. F., De Yoreo, J. J., and Dove, P. M., 2009. Carboxylated molecules regulate magnesium content of amorphous calcium carbonates during calcification. PNAS $106,21511-16$.

Warthmann, R., Van Lith, Y., Vasconcelos, C., McKenzie, J.A., and Karpoff, A., 2000, Bacterially induced dolomite precipitation in anoxic culture experiments. Geology 28, $1091-1094$.

Windom, H.L., Schropp, S.J., Calder, F.D., Ryan, J.D., Smith Jr., R.G., Burney, F.G., Lewis, L.C., Rawlinson, C.H., 1989. Natural trace metal concentrations in estuarine and coastal marine sediments of the southeastern United States. Environ. Sci. Technol. 23, 314-320. 
1 Wright, D.T., and Wacey, D., 2005. Precipitation of dolomite using sulphate-reducing bacteria

2 from the Coorong Region, South Australia: significance and implications. Sedimentology $3 \quad 52,987-1008$.

4 Wright, J.E., Wyld, S.J., 2011. Late Cretaceous subduction initiation on the eastern margin of the 5 Caribbean-Colombian Oceanic Plateau. One Great Arc of the Caribbean (?). Geosphere $6 \quad 7,468-493$.

7 Yang, Y., Sahai, N., Romanek, C.S., and Chakraborty, S., 2012. A computational study of $\mathrm{Mg}^{2+}$ 8 dehydration in aqueous solution in the presence of $\mathrm{HS}^{-}$and other monovalent anions 9 Insights to dolomite formation. Geochimica et Cosmochimica Acta 88, 77-87.

10 Zhang, F., Xu, H., Konishi, H., Kemp, J.M., Roden, E.E., and Shen, Z., 2012. Dissolved sulfide11 catalyzed precipitation of disordered dolomite: Implications for the formation mechanism of 12 sedimentary dolomite. Geochimica et Cosmochimica Acta 97, 148-165. 


\section{FIGURE CAPTIONS}

2 Figure 1. Archipiélago Los Roques National Park, Venezuela. A: The Archipelago consists of

3 more than 42 cays, most of them exhibiting at least one restricted lagoon. B: The selected study

4 site is the hypersaline lagoon Francisqui del Medio. C: Desiccated microbial mats remain as

5 evidence of seasonal variations in the lagoonal water level. D: The communities comprising

6 these mats produce copious amounts of exopolymers (EPS).

8 Figure 2. Reactivity of the surficial microbial mat. Organic functional groups comprising the 9 microbial biomass confer it with a strong capacity for metal sorption. A: Functional group 10 distribution modelled from titration data for upper (green) and lower (purple) photosynthetic mat

11 layers from the hypersaline lagoon in Francisqui. The model represents the set of functional 12 groups, fitted in terms of concentration (y-axis, normalized to dry weight) over a fixed grid of 13 possible acidity constants ( $\mathrm{x}$-axis, in this case from 3 to 11 in $0.2 \mathrm{pK}_{\mathrm{a}}$ increments), that best

14 describes the charge excess data over three titration replicates. B: SR-FTIR-ATR spectrum of 15 microbial biomass. C: Logarithmic plot showing enrichment/depletion factors $\left(\mathrm{D}_{\mathrm{Me}}=\right.$ $\left.16\left([\mathrm{Me}]_{\mathrm{Sed}} /[\mathrm{Me}]_{\mathrm{lw}}\right) \cdot\left([\mathrm{Ca}]_{1 \mathrm{w}} /[\mathrm{Ca}]_{\mathrm{Sed}}\right)\right)$ for the first row transition metals in the sediments and surface

17 mat relative to lagoon waters. D: Transmitted electron micrographs of filamentous and coccoid 18 microorganisms associated with $\mathrm{S}^{0}$-rich mats. Note extracellular, intracellular, and cytoplasmic 19 membrane sulfur inclusions, as determined by EPMA.

21 Figure 3. Bulk sedimentological and geochemical trends along the studied interval. TOC values 22 of the lagoonal facies range from 0.24 to $4.56 \mathrm{wt} \%$. In the first $10 \mathrm{~cm}$ of the sedimentary pile, 23 TOC is approximately equal to the reciprocal of $\operatorname{depth}^{-1 / 2}$; a significant increase in TOC values 
1 occurs below $11 \mathrm{~cm}$ depth. The bulk sediment trace metal enrichment/depletion trends were

2 normalized using concentrations measured at the microbial mat sediment interface $\left(\mathrm{D}_{\mathrm{Me}}=\right.$

$3\left([\mathrm{Me}]_{\mathrm{Sed}} /[\mathrm{Me}]_{\mathrm{lw}}\right) \cdot\left([\mathrm{Ca}]_{I_{\mathrm{w}}} /[\mathrm{Ca}]_{\mathrm{Sed}}\right)$, see also Table 1$)$. Areas influenced by the microbial mats are

4 shown in light grey, with darker grey showing the living surficial microbial mat.

6 Figure 4. Dendrogram representing the outcome of a hierarchical cluster analysis of bulk 7 sediment composition (fraction soluble in $8 \mathrm{M} \mathrm{HNO}_{3}$, thus excluding refractory detrital minerals).

9 Figure 5. Textural and electron probe microanalyses of the dolomite-bearing interval. A: High 10 magnification SEM photomicrograph and EDS spectrum of the Ca-dolomite cements, the latter 11 associated with decaying EPS (arrow). B: $\mathrm{MgCO}_{3}-\mathrm{CaCO}_{3}-\mathrm{FeCO}_{3}$ triangular plot of cement 12 composition based on WDS data. C: More efficient degradation of sedimentary organic matter is 13 observed in the Mg and Mn enriched interval (data from ICP-MS). D: Backscattered electron 14 imaging and composite $\mathrm{Ca}, \mathrm{S}, \mathrm{Mg}$ elemental maps (EMPA) provide evidence for the replacement 15 of gypsum by aragonite, and the distribution of Ca-dolomite and elemental sulfur in the $8-10 \mathrm{~cm}$ 16 depth interval. Note the decrease in $\mathrm{S}^{0}$ accumulation in interstitial areas occluded by $\mathrm{Mg}$ 17 enriched carbonates.

19 Figure 6. SEM micrograph and EDS spectrum of Ca-hydroxyapatite at 13-cm depth.

21 Figure 7. Synchrotron-based $\mu$-XRD. A: Close up of the 2D integrated pattern (inset) obtained

22 over the analytical area $\left(\sim 30 \mu \mathrm{m}^{2}\right)$ shown in B (arrow) at this location. The dominant phases are 23 microcrystalline high- $\mathrm{Mg}$ calcite, aragonite, and Ca-dolomite $\left(d_{104}=2.901 \AA\right)$. B: SEM 
1 micrograph showing a micritized hydrobiid gastropod shell and associated micritic cements. See

2 also Fig. 8.

4 Figure 8. Micro-XRF distribution maps $\left(400 \times 600 \mu \mathrm{m}^{2}\right)$ showing zones of preferential 5 enrichment of $\mathrm{Ca}$ (B) $\mathrm{Mn}$ (C) and $\mathrm{Ni}$ (D) in the cements. The color-coding convention is 6 presented on the scale bar $(300 \mu \mathrm{m}$ in size $)$; it assigns blue to the minimum and red to maximum 7 deconvoluted peak area of the element.

9 Figure 9. Normalized Mn K-edge merged spectra of the analytical area shown in Fig. 7B 10 (arrow). A. The K-edge exhibits two main features at about 6554 and $6558 \mathrm{eV}$. B: Intermediate 11 valence $\mathrm{Mn}$ (III) is identified by using the first derivative of the XANES spectra in the interval 12 6547.9-6549.0 eV (e.g., Manceau et al., 2012). C: A least-square fitting of the spectra was 13 performed to quantify the Mn species present. The spectra can be fitted with four model 14 compounds, $\mathrm{Mn}_{2} \mathrm{O}_{3}(52.5 \pm 5.2 \%), \mathrm{MnCO}_{3}(22.2 \pm 1.3 \%)$, $-\mathrm{MnOOH}(15.0 \pm 5.0 \%)$, and $\mathrm{Mn}_{3} \mathrm{O}_{4}$ $15(10.3 \pm 7.7 \%)$, suggesting that co-occurrence of these phases in the dolomite-bearing 16 microcrystalline cements.

18 Figure 10. Schematic showing a simplified coupled sedimentary manganese-sulfur cycle as 19 envisioned in the dolomite-cemented interval associated with the buried microbial mat. The 20 envisioned in the dolomite-cemented interval associated with the buried. $\mathrm{T}$ theoretical calculation 21 of energy yield of each reaction is also shown (This diagram is not mass or charge balanced. See 22 details in text: reactions $1-4)$ 


\section{TABLE CAPTIONS}

2 Table 1. Lagoon water and bulk-sediment trace element concentrations. Grey shadowed zone

3 represents the living microbial mat, values in bold the Ca-dolomite cemented interval of buried

4 microbial mat. See also Supplementary Table 1.

5

6 Table 2. Activity of dissolved species and saturation indexes (SI) of predicted mineral phases

$7(\Omega>0)$ in the surficial lagoon water as determined using the chemical speciation code WATEQ4F

8 as implemented in PHREEQC (Parkhust and Appelo, 1999).

9

10 Table 3. Semi quantitative $\mu$-XRF concentration data (Units in ppm)

11 

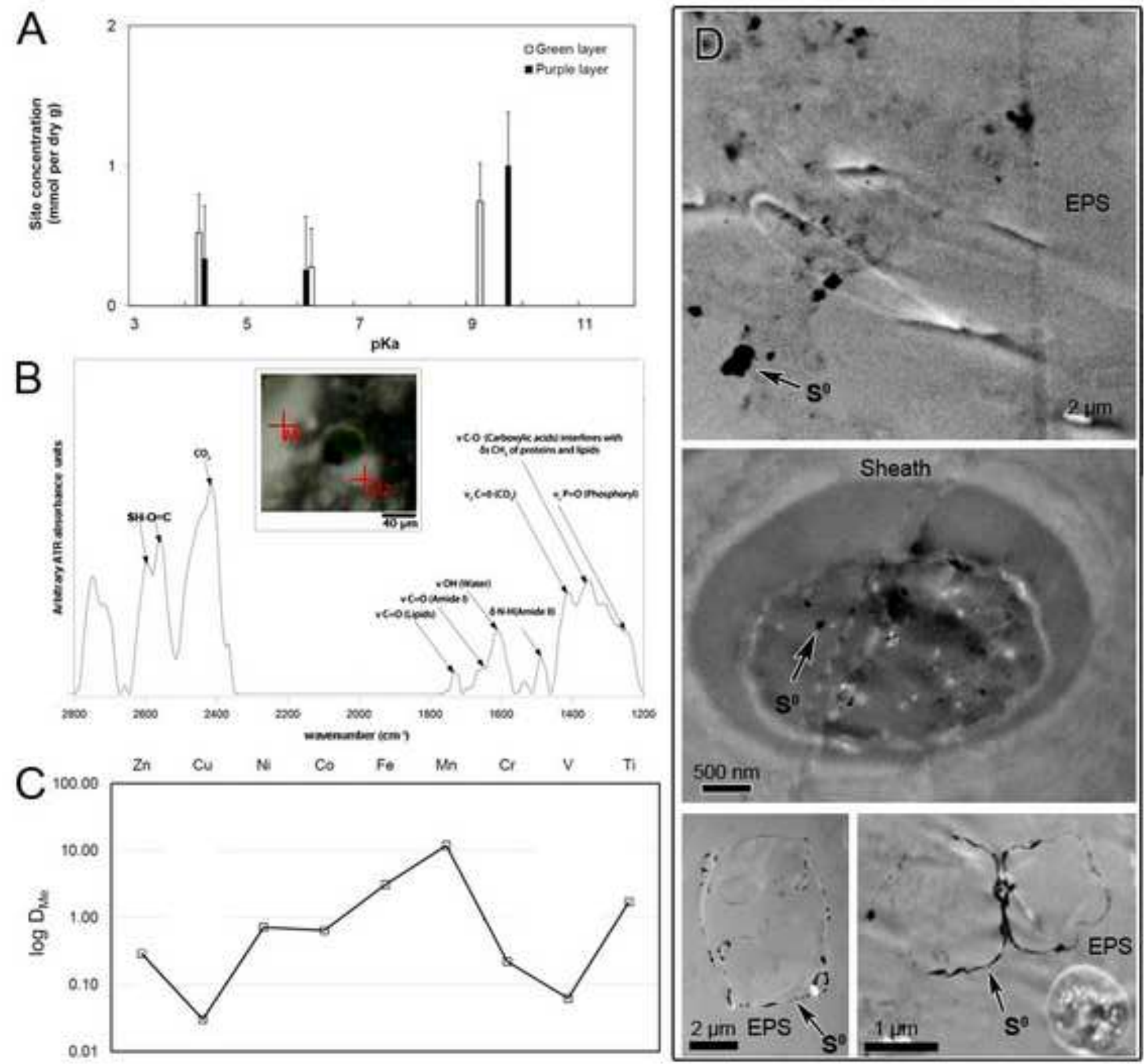

B

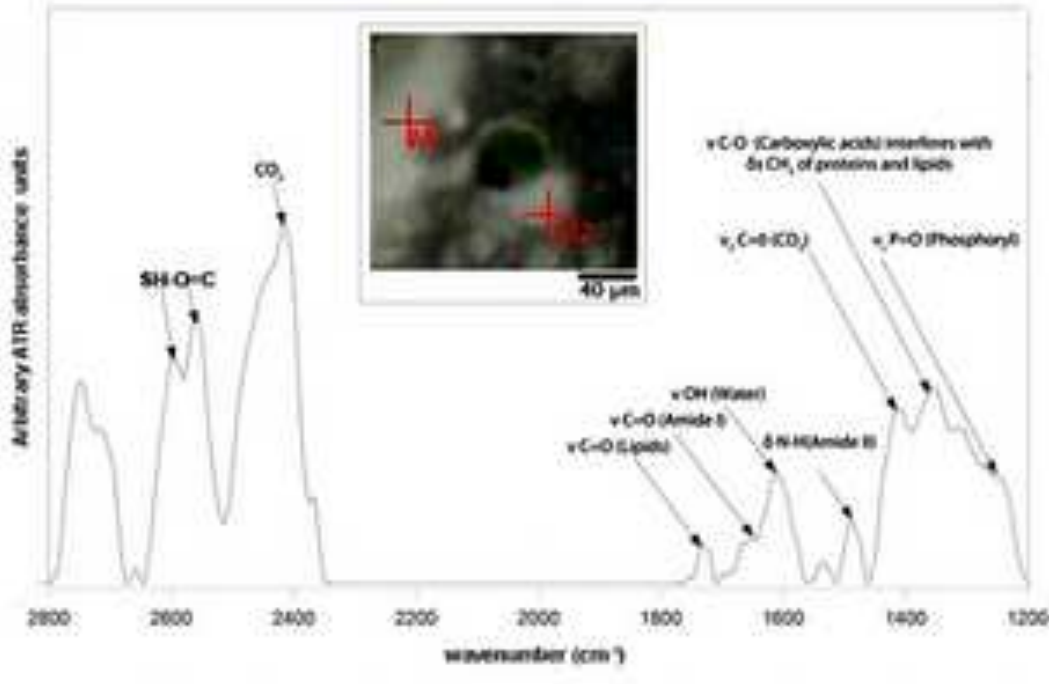

C

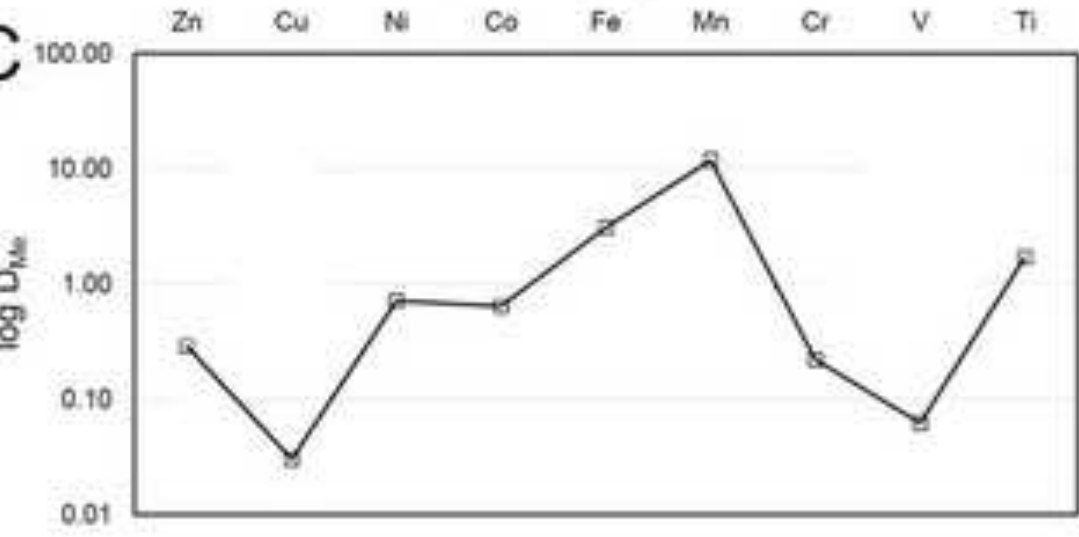




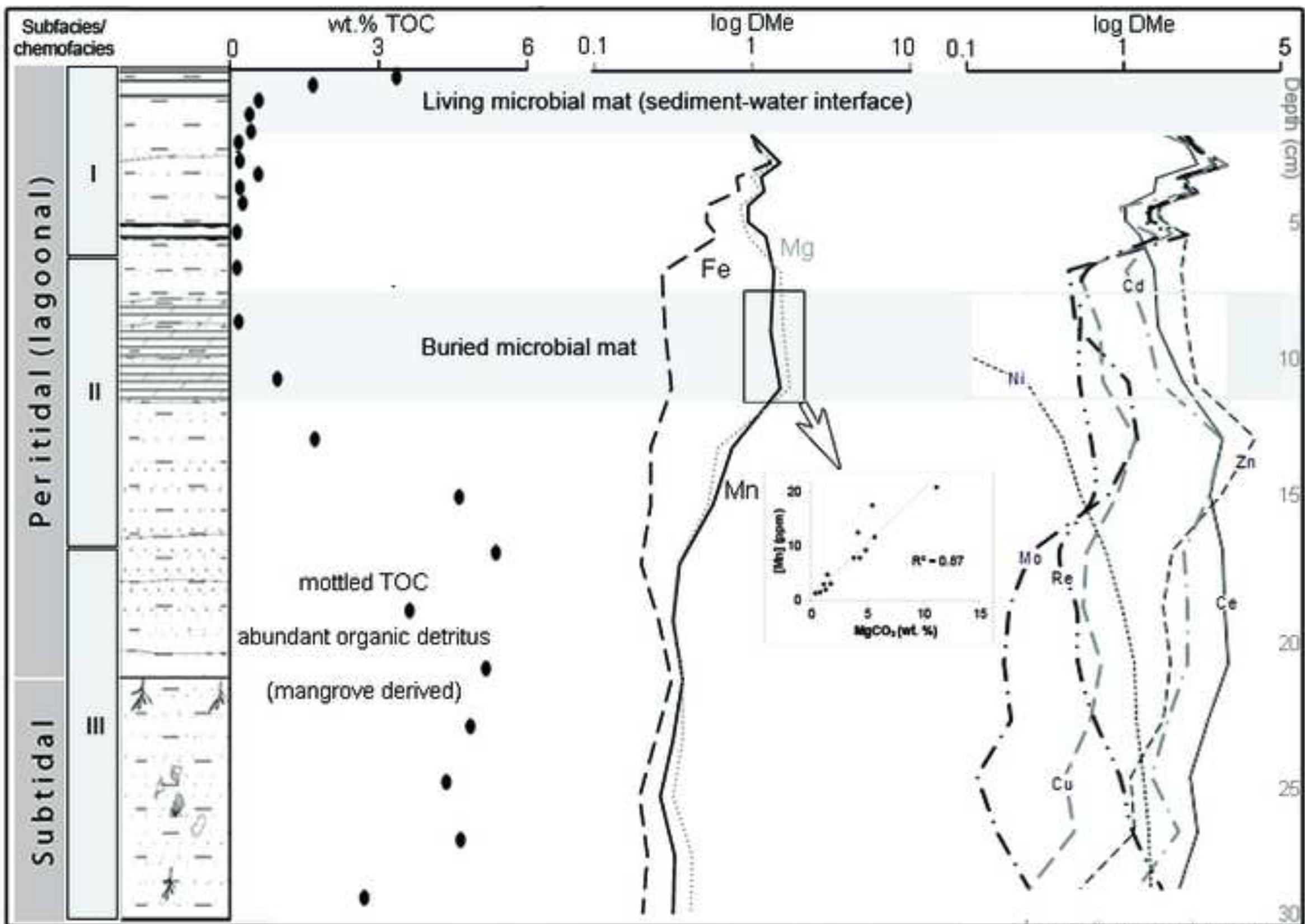

Carbonate mud and sand cemented by dolomicrite Composite set of planar, wavy and crinckled laminae.

Alochems, mostly micritized gastropods, can be present, 


\section{ranax}

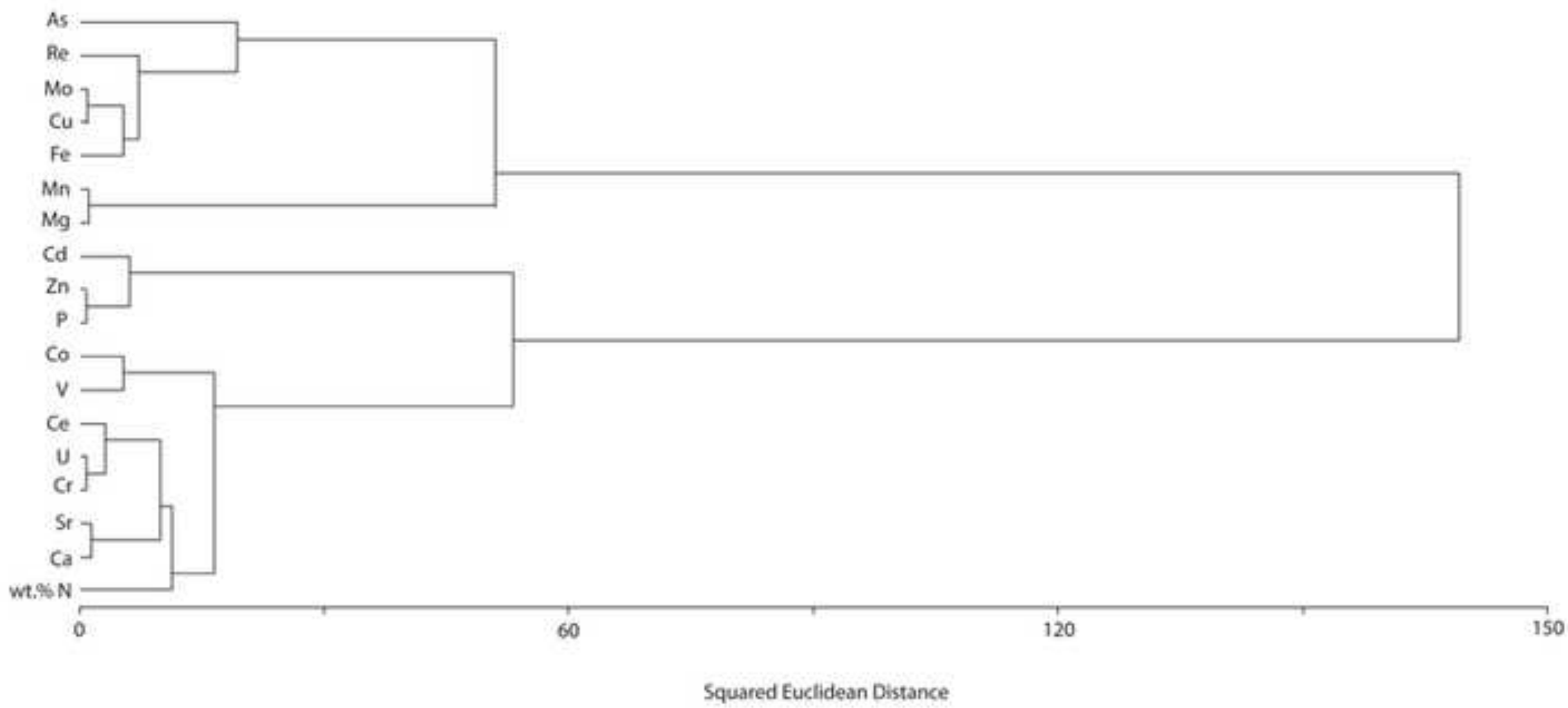

Squared Euclidean Distance 

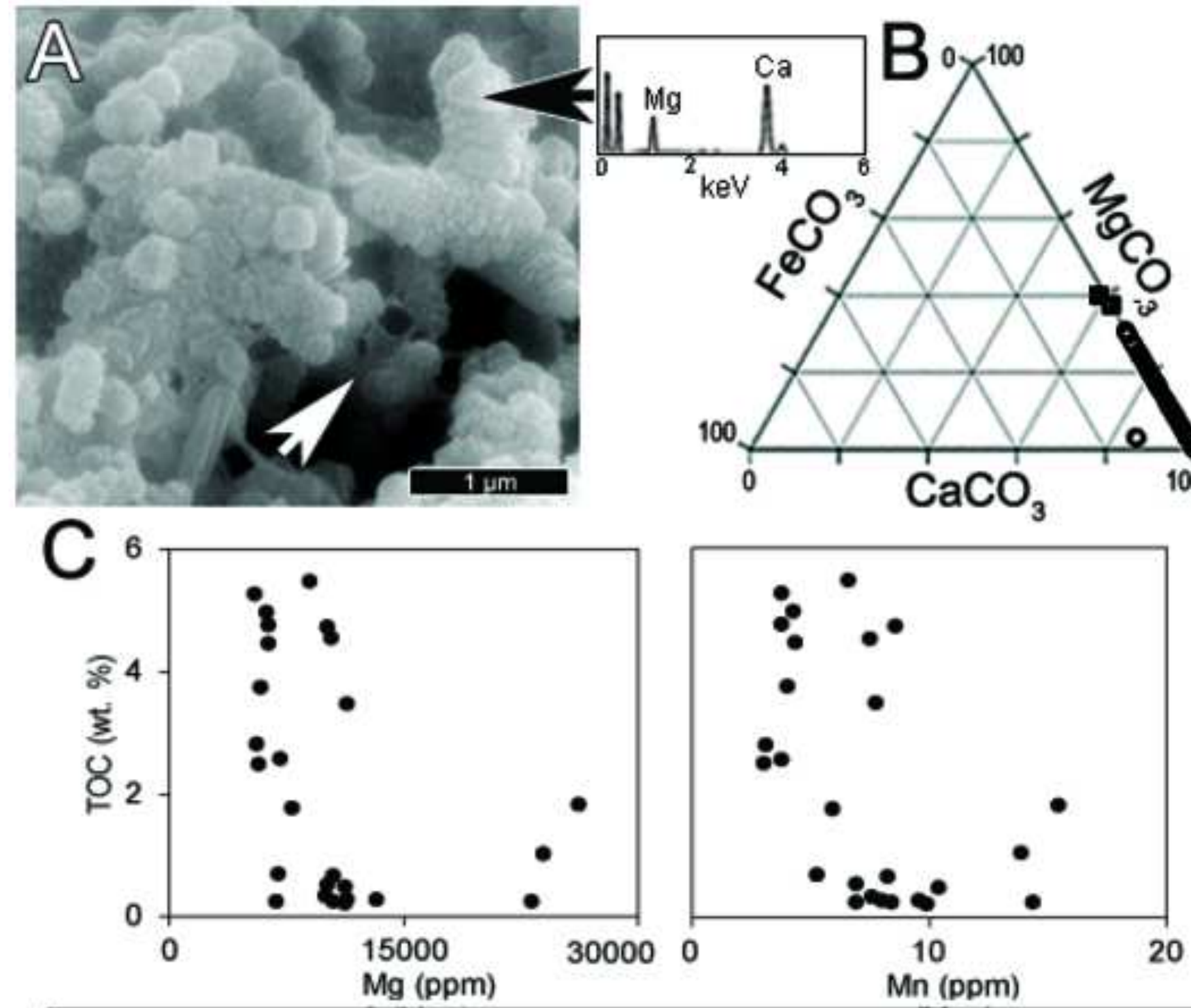

Gy: $6.86 \%$

$\mathrm{HMC}+\mathrm{Ca}-\mathrm{Dol}: 8.66 \%$ Arag : $57.97 \%$

$\mathrm{S}^{\mathrm{0}}: 0.43 \%$

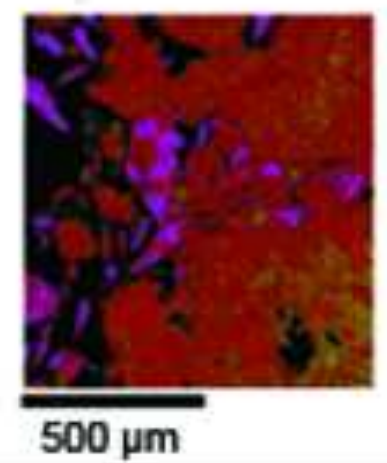

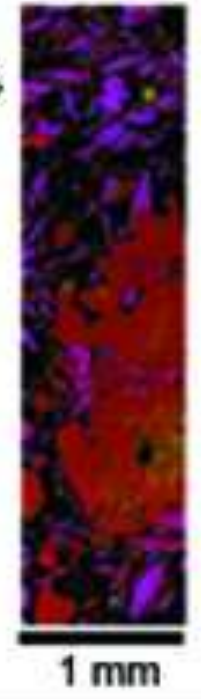

Gy: $0.05 \%$;

$\mathrm{HMC}+\mathrm{Ca}-\mathrm{Dol}: 29.41 \%$ Arag : $35.80 \%$; IS: $0.01 \%$

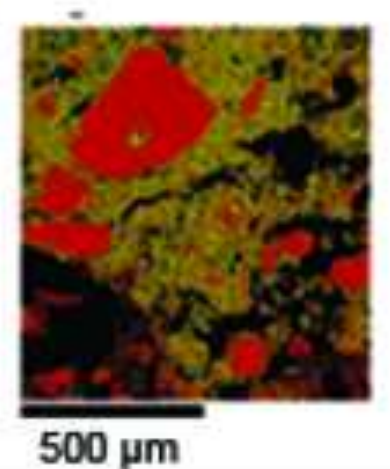

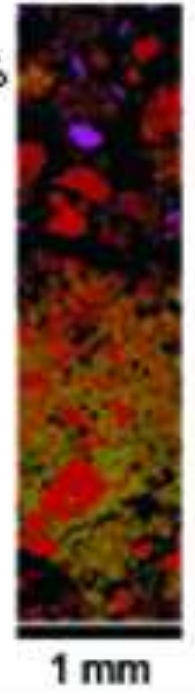



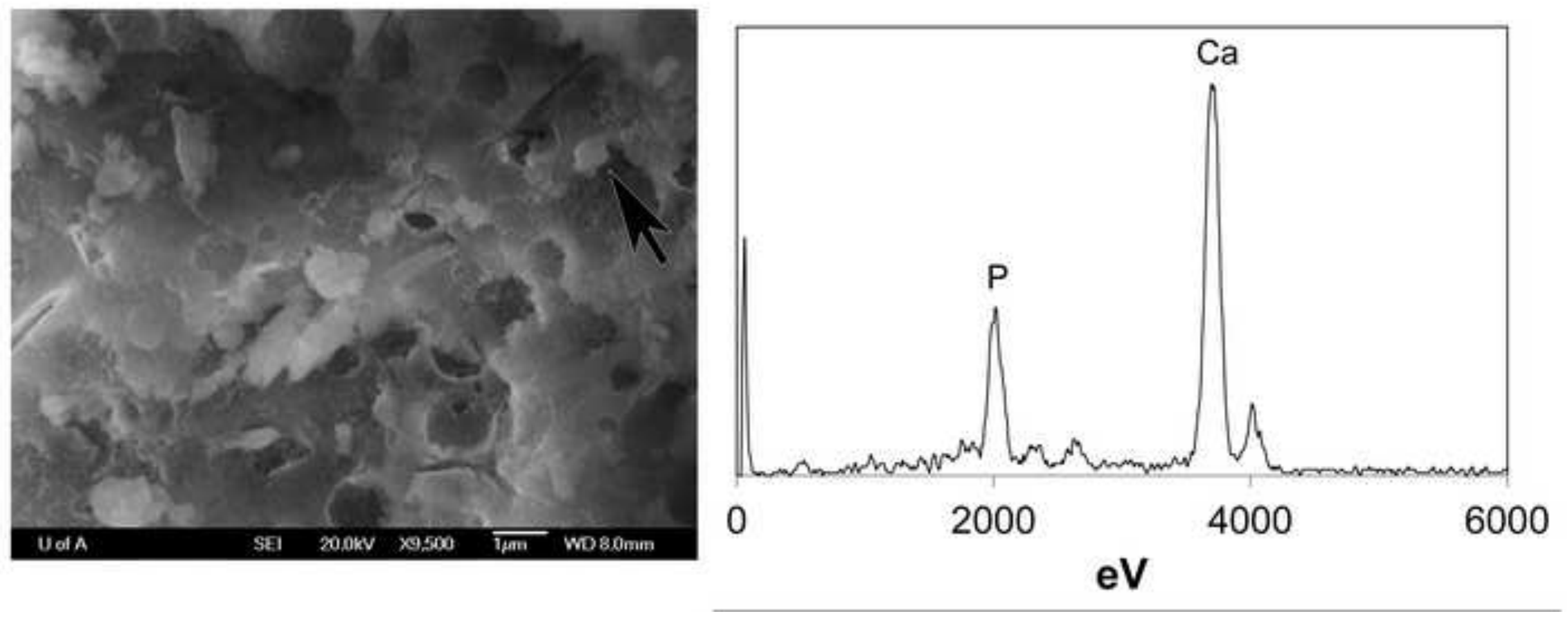
Figure 9
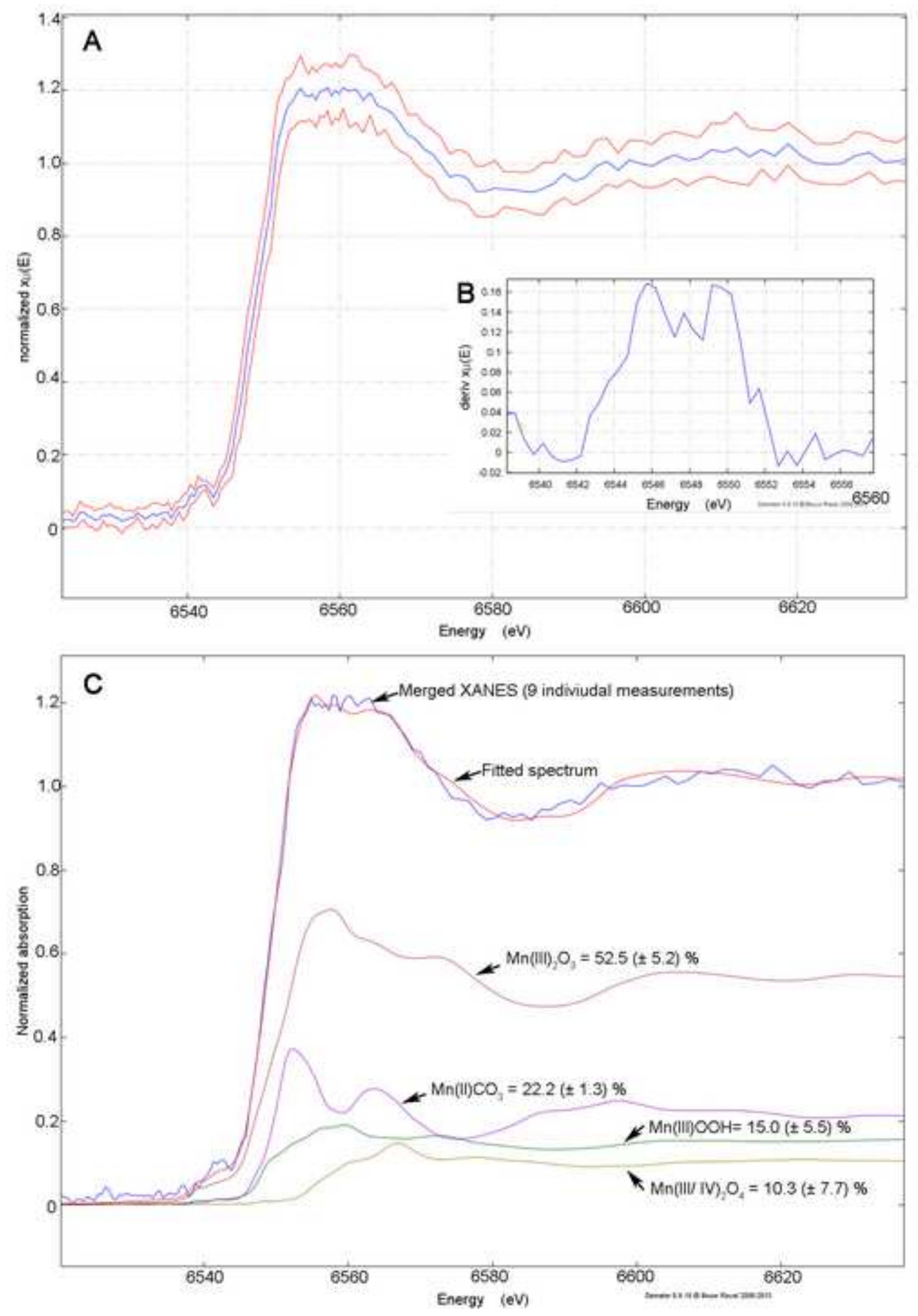


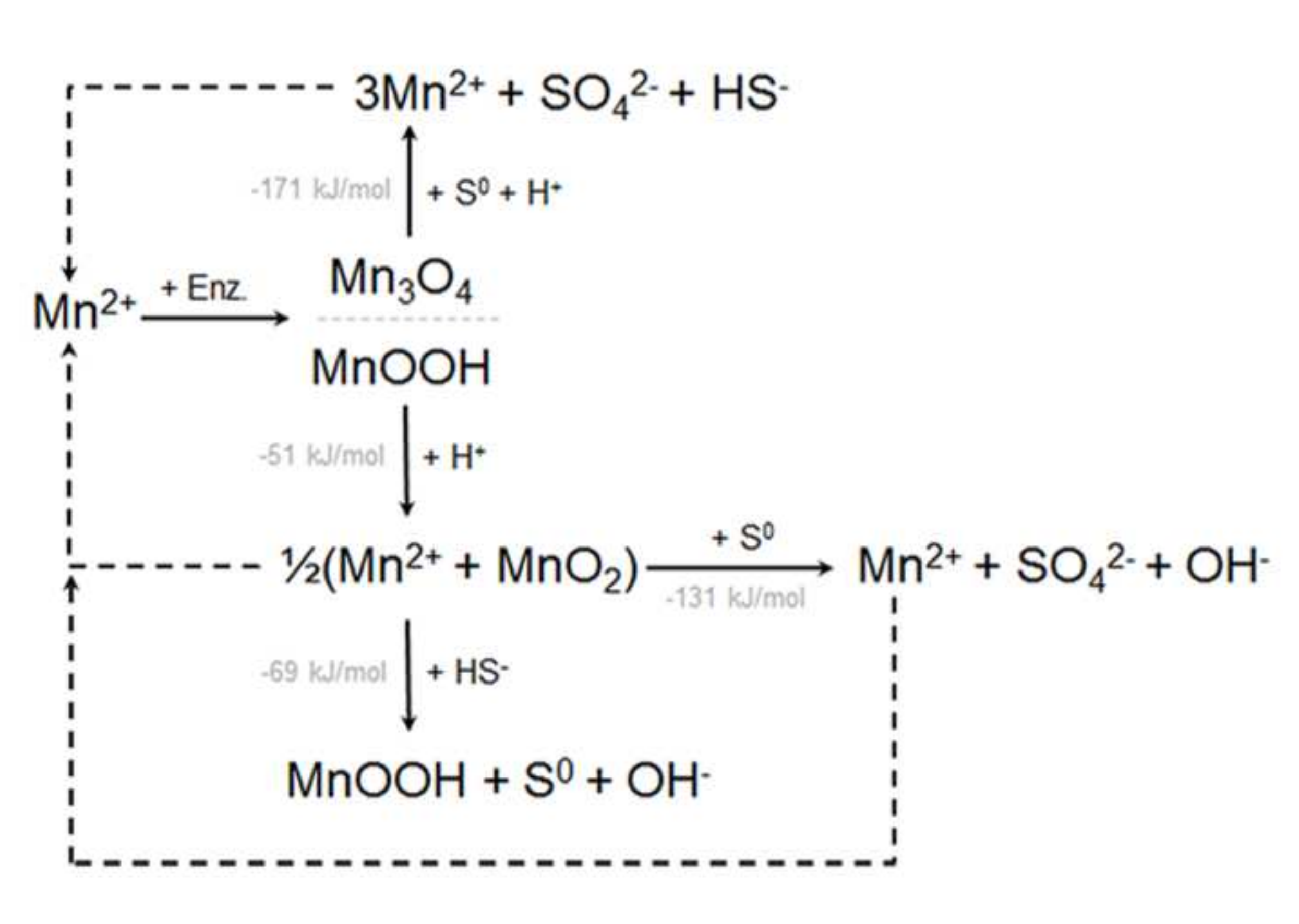

\section{$\mathrm{MnOOH}$}

$-1 / 2\left(\mathrm{Mn}^{2+}+\mathrm{MnO}_{2}\right) \underset{-131 \mathrm{~kJ} / \mathrm{mol}}{\longrightarrow} \mathrm{Mn}^{2+}+\mathrm{SO}_{4}^{2-}+\mathrm{OH}^{-}$ $-69 \mathrm{~kJ} / \mathrm{mol} \downarrow+\mathrm{HS}$ -

$\mathrm{MnOOH}+\mathrm{S}^{0}+\mathrm{OH}^{-}$

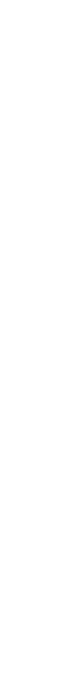




\section{Table 1}

\begin{tabular}{|c|c|c|c|c|c|c|c|c|c|c|}
\hline Analyte & $\mathbf{T i}$ & $\mathbf{V}$ & $\mathrm{Cr}$ & Mn & $\mathbf{F e}$ & Co & $\mathbf{N i}$ & $\mathbf{C u}$ & $\mathbf{Z n}$ & Mo \\
\hline$[\mathrm{Me}]_{\mathrm{lw}}$ & 2.95 & 4.87 & 0.32 & 1.25 & 1.64 & 0.12 & 0.50 & 18.41 & 1.24 & 1.63 \\
\hline Depth & $\mathbf{T i}$ & $\mathbf{V}$ & $\mathrm{Cr}$ & Mn & $\mathrm{Fe}$ & Co & $\mathbf{N i}$ & $\mathrm{Cu}$ & Zn & Mo \\
\hline 0.25 & 159.9 & 43.3 & 41.6 & 140.1 & $6,179.2$ & 13.4 & 202.3 & 39.3 & 81.23 & 52.0 \\
\hline 0.75 & 82.7 & 27.4 & 25.3 & 106.9 & $4,654.6$ & 1.4 & <D.L. & 45.2 & 74.49 & 48.2 \\
\hline 1.25 & 78.0 & 26.8 & 22.6 & 94.8 & $4,253.4$ & 1.1 & <D.L. & 46.6 & 102.32 & 69.5 \\
\hline 1.75 & 169.6 & 66.1 & 45.0 & 189.1 & $7,331.7$ & 1.7 & $<$ D.L. & 122.1 & 203.37 & 155.9 \\
\hline 2.25 & 159.5 & 36.7 & 29.0 & 124.9 & $5,044.4$ & 0.7 & <D.L. & 60.9 & 113.50 & 91.3 \\
\hline 2.75 & 117.5 & 45.6 & 31.4 & 151.7 & $5,507.4$ & 1.1 & $<$ D.L. & 80.7 & 153.90 & 105.5 \\
\hline 3.25 & 131.0 & 51.9 & 40.1 & 174.0 & $6,163.6$ & 1.8 & $<$ D.L. & 107.2 & 177.66 & 150.3 \\
\hline 3.75 & 92.4 & 35.7 & 26.7 & 148.7 & $4,231.9$ & 0.5 & <D.L. & 63.8 & 129.57 & 88.8 \\
\hline 4.25 & 87.2 & 34.6 & 26.2 & 145.6 & $4,041.8$ & 0.6 & <D.L. & 74.3 & 143.91 & 92.5 \\
\hline 4.75 & 69.5 & 25.1 & 21.5 & 137.8 & $3,056.2$ & $<$ D.L. & $<$ D.L. & 50.4 & 99.89 & 60.8 \\
\hline 5.25 & 76.9 & 25.3 & 22.0 & 136.5 & $3,056.2$ & $<$ D.L. & $<$ D.L. & 50.0 & 101.35 & 59.7 \\
\hline 5.75 & 87.5 & 20.9 & 17.9 & 125.1 & $2,692.3$ & $<$ D.L. & $<$ D.L. & 39.1 & 118.33 & 107.4 \\
\hline 7 & 127.4 & 32.8 & 29.3 & 178.8 & $3,613.5$ & $<$ D.L. & $<$ D.L. & 61.3 & 150.15 & 24.3 \\
\hline 9 & 109.9 & 28.6 & 36.0 & 260.4 & $2,090.9$ & 2.1 & <D.L. & 20.0 & 179.73 & 27.1 \\
\hline 11 & 129.6 & 39.3 & 39.9 & 252.3 & $2,207.0$ & 3.3 & 5.5 & 27.7 & 195.53 & 57.7 \\
\hline 13 & 123.2 & 35.1 & 49.7 & 280.7 & $2,409.7$ & 4.7 & 32.1 & 29.0 & 219.64 & 70.3 \\
\hline 15 & 630.3 & 58.3 & 70.9 & 155.0 & $1,940.4$ & 5.7 & 59.6 & 49.4 & 569.28 & 47.7 \\
\hline 17 & 452.1 & 50.7 & 70.9 & 119.2 & $1,940.2$ & 6.8 & 79.3 & 39.2 & 346.77 & 15.2 \\
\hline 19 & 165.0 & 50.4 & 69.5 & 73.3 & $1,714.7$ & 8.5 & 115.3 & 24.6 & 172.28 & 11.5 \\
\hline 21 & 196.2 & 62.8 & 74.9 & 68.2 & $2,255.8$ & 10.3 & 147.5 & 24.3 & 155.66 & 10.3 \\
\hline 23 & 206.6 & 87.5 & 88.2 & 76.8 & $2,615.2$ & 11.4 & 174.8 & 30.9 & 167.64 & 11.5 \\
\hline 25 & 239.3 & 89.2 & 89.5 & 79.3 & $2,697.7$ & 13.3 & 200.0 & 31.3 & 165.94 & 7.0 \\
\hline 27 & 191.2 & 89.0 & 80.0 & 68.1 & $2,102.6$ & 11.3 & 180.9 & 26.6 & 152.11 & 7.3 \\
\hline 29 & 117.1 & 101.6 & 70.6 & 56.9 & $1,686.6$ & 12.1 & 204.0 & 18.8 & 94.51 & 15.2 \\
\hline SE & 7.9 & 0.6 & 0.5 & 1.8 & 18.9 & 0.7 & 9.4 & 0.7 & 1.4 & 0.4 \\
\hline
\end{tabular}

Concentrations are given in $\mathrm{nmol} \cdot(\mathrm{g} \text { dry wt. })^{-1}$, except for $[\mathrm{Me}]_{\mathrm{lw}}$ (concentrations measured in the surficial lagoon water) which are in $\mathrm{nM}$; $\mathrm{SE}$ : measured standard error (based in 3 replicates) 


\section{Table 2}

\begin{tabular}{|c|c|c|c|c|}
\hline Phase & & SI & $\log$ IAP & $\log \mathrm{KT}$ \\
\hline Goethite & $\mathrm{FeOOH}$ & 7.0 & 5.7 & -4.7 \\
\hline Huntite & $\mathrm{CaMg}_{3}\left(\mathrm{CO}_{3}\right)_{4}$ & 5.8 & -24.7 & 2.7 \\
\hline Maghemite & $\mathrm{Fe}_{2} \mathrm{O}_{3}$ & 5.0 & 11.3 & -9.0 \\
\hline Dolomite(d) & $\mathrm{CaMg}\left(\mathrm{CO}_{3}\right)_{2}$ & 4.0 & -12.8 & -3.0 \\
\hline Hydromagnesite & $\mathrm{Mg}_{5}\left(\mathrm{CO}_{3}\right)_{4}(\mathrm{OH})_{2} \cdot 4 \mathrm{H}_{2} \mathrm{O}$ & 3.5 & -6.4 & -30.5 \\
\hline Artinite & $\mathrm{MgCO}_{3} \cdot \mathrm{Mg}(\mathrm{OH})_{2} \cdot 3 \mathrm{H}_{2} \mathrm{O}$ & 2.6 & 11.6 & 6.4 \\
\hline Magnesite & $\mathrm{MgCO}_{3}$ & 2.2 & -6.0 & -17.3 \\
\hline Calcite & $\mathrm{CaCO}_{3}$ & 1.8 & -6.8 & 9.0 \\
\hline Aragonite & $\mathrm{CaCO}_{3}$ & 1.6 & -6.8 & -8.2 \\
\hline Brucite & $\mathrm{Mg}(\mathrm{OH})_{2}$ & 1.4 & 17.6 & 6.9 \\
\hline Hausmannite & $\mathrm{Mn}_{3} \mathrm{O}_{4}$ & 1.3 & 60.1 & 7.3 \\
\hline $\mathrm{Fe}(\mathrm{OH})_{3}(\mathrm{a})$ & $\mathrm{Fe}(\mathrm{OH})_{3}$ & 0.7 & 5.6 & -8.4 \\
\hline Strontianite & $\mathrm{SrCO}_{3}$ & 0.3 & -9.0 & 16.3 \\
\hline Gypsum & $\mathrm{CaSO}_{4} \cdot 2 \mathrm{H}_{2} \mathrm{O}$ & 0.3 & -4.3 & 58.9 \\
\hline Celestite & $\mathrm{SrSO}_{4}$ & 0.2 & -6.5 & 8.3 \\
\hline Bixbyite & $\mathrm{Mn}_{2} \mathrm{O}_{3}$ & 0.04 & -0.9 & -6.7 \\
\hline
\end{tabular}

Activity of dissolved species and saturation indexes (SI) of predicted mineral phases in the surficial lagoon waters. SI=log (IAP/ Ksp), with IAP and Ksp being the ion activity product of the dissolved constituents and solubility product, respectively. Calculation were performed using the following parameters: Salinity= | $140 \% ; \mathrm{pH}=9.3 ; \mathrm{CaCO}_{3(\mathrm{Tot})}=259 \mathrm{meq} / \mathrm{L} ;\left[\mathrm{Cl}^{-}\right]=77,260 \mathrm{mg} / \mathrm{L},\left[\mathrm{SO}_{4}^{-}\right]=13,269 \mathrm{mg} / \mathrm{L} ; \mathrm{Mg} / \mathrm{Ca}=6.1$, with dissolved concentrations of $[\mathrm{Ca}]=1,370 ;$ and $[\mathrm{Sr}]=274$; $[\mathrm{Fe}]=9.16 \cdot 10^{-2},[\mathrm{Mn}]=6.9 \cdot 10^{-3},[\mathrm{Zn}]=7.33 \cdot 10^{-2},[\mathrm{Cu}]=1.16 \mathrm{ppm}$. 
Table 3

Zone A (micritized snail)

\begin{tabular}{llllllll} 
MCA & Ti & V & Mn & Fe & Co & Ni & Cu \\
\hline $1-1$ & 1.11 & 1.52 & 5.82 & 71.71 & 0.41 & 1.16 & 1.03 \\
$1-2$ & 0.80 & 2.70 & 3.63 & 40.87 & 0.93 & 1.13 & 0.52 \\
$1-3$ & 0.32 & 0.25 & 2.31 & 41.47 & 1.34 & 0.17 & 0.69 \\
$1-4$ & 0.33 & 0.25 & 2.66 & 42.01 & 1.36 & 0.17 & 0.70 \\
$1-5$ & 0.44 & 1.14 & 1.12 & 34.59 & 1.39 & 0.14 & 0.37 \\
$1-6$ & 1.74 & 0.96 & 5.22 & 35.99 & 0.36 & 0.88 & 0.43 \\
\hline SD & 0.56 & 0.92 & 1.80 & 13.71 & 0.48 & 0.50 & 0.24 \\
\hline
\end{tabular}

Zone B: (microcrystalline dolomite-bearing cements)

\begin{tabular}{llllllll}
\hline MCA & Ti & V & Mn & Fe & Co & Ni & Cu \\
\hline $2-1$ & 0.78 & 0.69 & 19.96 & 71.51 & 3.58 & 0.12 & 0.75 \\
$2-2$ & 0.28 & 1.63 & 18.89 & 118.31 & 1.85 & 0.22 & 0.73 \\
$2-3$ & 1.98 & 0.28 & 31.93 & 156.72 & 5.57 & 0.15 & 1.31 \\
$2-4$ & 0.17 & 0.46 & 21.26 & 343.04 & 2.36 & 4.49 & 1.36 \\
$2-5$ & 1.30 & 2.74 & 18.98 & 130.38 & 7.94 & 0.57 & 0.56 \\
\hline SD & 0.75 & 1.03 & 5.52 & 104.74 & 2.51 & 1.90 & 0.37 \\
\hline
\end{tabular}

Units are ppm. Measured in an area of $6 \times 5 \mu \mathrm{m}$ 